\title{
The Effects of NMDA Receptor Antagonists and Nitric Oxide Synthase Inhibitors on Opioid Tolerance and Withdrawal Medication Development Issues for Opiate Addiction
}

Barbara H. Herman, Ph.D., Frank Vocci, Ph.D., and Peter Bridge, M.D.

This article is an exploration of the National Institute on Drug Abuse (NIDA) Technical Review on the role of glutamatergic systems in the development of opiate addiction. The effects of "glutamate antagonist" medications on opioid tolerance and withdrawal are examined. In rodents, mu opioid tolerance can be inhibited by noncompetitive N-methyl D-aspartate (NMDA) receptor antagonists IMK801, dextromethorphan (DM), ketamine, phencyclidine $(P C P)]$, competitive NMDA receptor antagonists (LY274614, NPC17742, LY235959), partial glycine agonists $(A C P C)$, glycine antagonists $(A C E A-1328)$, and nitric oxide synthase (NOS) inhibitors [L-NNA, L-NMMA, methylene blue (MB)]. Similarly, some of the symptoms of opioid withdrawal observed in opioid-

KEY WORDS: NMDA receptor; Nitric oxide; Tolerance; Withdrawal; Opiate addiction; Morphine

From the Medications Development Division, National Institute on Drug Abuse, National Institutes of Health, Rockville, MD.

Address correspondence to Barbara H. Herman, Ph.D., Director. Clinical Opioid Medications Program, Clinical Trials Branch, Medications Development Division, National Institute on Drug Abuse, 5600 Fishers Lane, Room 11A55, Rockville, MD 20857.

Received

The opinions expressed herein are the views of the authors and may not necessarily reflect the official policy or position of the $\mathrm{Na}$ tional Institute on Drug Abuse or any other part of the U.S. Depart ment of Health and Human Services. The U.S. government does not endorse or favor any specific commercial product or company. Trade, proprietary, or company names appearing in this publication are used only because they are considered essential in the context of the studies reported. dependent rodents also can be inhibited by noncompetitive NMDA receptor antagonists (MK801, DM, ketamine), competitive NMDA receptor antagonists (LY274614), glycine antagonists (felbamate), and NOS inhibitors ( L-NNA, L-NMMA, L-NAME, L-NIO, 7-NI, MB). There are some serious toxicological effects associated with the administration of some of the noncompetitive NMDA receptor antagonists in rodent but not in squirrel monkey brain, and some medications induce PCP-like behavioral effects. The medications with the most immediate clinical appeal are those that could be coadministered with methadone to decrease $m u$ opioid tolerance and dependence; they include $D M, M B, 7-N I$, $A C P C$, and ACEA-1328. [Neuropsychopharmacology 13:269-293, 1995]

On October 17 and 18, 1994, the National Institute on Drug Abuse (NIDA) held a technical review entitled, "The Role of Glutamatergic Systems in the Development of Opiate Addiction" (B. H. Herman and D. Majewska, chairs). The technical review focused on the effects of drugs that block the NMDA receptor complex (NMDA-RC) in the process of opioid tolerance and withdrawal. There were twelve scientific presentations providing an overview of virtually every aspect of this question from the molecular biology of glutamate receptors to preclinical and clinical investigations examining the effects of this class of drugs on these aspects of opiate addiction. The present review summarizes the major findings of some of these presenting scientists and the research of many other investigators. (For further details, refer to some of the individual original research 
publications and laboratory perspectives provided by these scientists in individual articles in this volume. For recent reviews of the diversity of agents that modify opioid tolerance and withdrawal see Bhargava 1994; Jaffe 1994; Jaffe and Martin 1994; Székely 1994; for a brief review of glutamate and opiate addiction, see Herman et al. 1993).

There is evidence from numerous laboratories that a variety of noncompetitive $\mathrm{N}$-methyl $\mathrm{D}$-aspartate (NMDA) receptor antagonists, competitive NMDA receptor antagonists, glycine antagonists, and nitric oxide synthase (NOS) inhibitors can inhibit $m u$ opioid (morphine) tolerance in the rodent (Marek et al. 1991a, 1991b; Trujillo and Akil 1991a, 1994; Ben-Eliyahu et al. 1992; Kolesnikov et al. 1992, 1993a, 1993b; Tiseo and Inturrisi 1993; Bhargava and Matwyshyn 1993; Gutstein and Trujillo 1993; Lufty et al. 1993, 1995; Tiseo et al. 1994; Babey et al. 1994; Elliott et al. 1994a, 1994b, and this volume; Bhargava 1995a; Matwyshyn and Bhargava 1995; Pasternak et al. this volume; Trujillo this volume). In addition, the potency and clinical potential of these agents on morphine tolerance are strengthened by the findings of several studies indicating that both noncompetitive and competitive NMDA receptor antagonists are capable of "reversing" morphine tolerance (Tiseo and Inturrisi 1993; Elliott et al. 1994a; see also Trujillo and Akil 1994). There is also evidence from a smaller number of laboratories that some of the symptoms of narcotic antagonist-precipitated opioid withdrawal observed in rodents exposed in a chronic fashion to a $m u$ opioid agonist such as morphine can also be inhibited by noncompetitive NMDA receptor antagonists, competitive NMDA receptor antagonists, glycine antagonists, and NOS inhibitors (Koyuncuoglu et al. 1990; Rasmussen et al. 1991; Tanganelli et al. 1991; Trujillo and Akil 1991a; Brent and Chahl 1993; Cappendijk et al. 1993; Kimes et al. 1993; Kolesnikov et al. 1993b; Vaupel et al. 1995 and in this volume; Kosten et al. this volume; Rasmussen this volume), although other investigators have failed to obtain significant effects of some of these agents on opioid withdrawal (Matwyshyn et al. 1993; Thorat et al. 1994; Matwyshyn and Bhargava 1995).

The mission of the Clinical Opioid Medications Program (COMP) of NIDA is to develop medications for the treatment of opiate addiction. The COMP is a program within the Clinical Trials Branch of the Medications Development Division (MDD) of NIDA. There is at least a twofold rationale for the development of medications for the treatment of opiate addiction. First, from an ethical and medical perspective, there are striking data indicating that orally administered methadone maintenance therapy decreases the mortality of intravenous (IV) heroin abusers about six- to eightfold in comparison with untreated abusers (Grönbladh et al. 1990 ). As of 1990 , at least $30 \%$ of AIDS cases were IV drug abusers in the United States, thereby providing a new and powerful impetus for the search for novel medications for the treatment of opiate addiction (Report of the National Commission on AIDS: The Twin Epidemics of Substance Abuse and HIV, July 1991). Second, in the United States, the cost to society for heroin addicts who go untreated is over 10-fold greater than individuals who are treated with methadone on an outpatient basis (NIDA). The overall cost of drug abuse in the United States in 1991 was estimated to be about $\$ 100$ billion if one includes factors such as the associated costs of care of addicted infants and the influence of drug abuse on the AIDS epidemic (Rice et al. 1991). Therefore, from an ethical, medical, and economic point of view, it is to the advantage of society to search for new medications for the treatment of opiate addiction.

Why would it be necessary to develop medications beyond methadone for the treatment of opiate addiction? In fact, besides methadone, a variety of other orally administered opiate agonists have been shown to be effective opiate maintenance medications. These include the recently Food and Drug Administration (FDA)approved medication L-alpha-acetylmethadol [LAAM, (Ling et al. 1976)] and the recently studied (but not yet FDA-approved) medication buprenorphine (Johnson et al. 1992). The COMP recognizes the value of these opioid agoinst medications for maintenance prior to detoxification, but it is doubtful whether another opioid or yet-untested nonopioid medication will prove superior for this indication. Therefore, the development of additional opioid medications for the "maintenance" of opiate-dependent individuals is no longer a priority for the COMP. On the other hand, methadone has not proven to be a good medication for preventing the relapse to IV-administered opiates in individuals who have been medically withdrawn from this medication. Ball and Ross (1991) showed that about $82 \%$ of opiate-dependent individuals previously maintained on methadone relapse to IV opiates about 1 year following cessation of methadone therapy. Accordingly, the development of medications that will prevent the relapse to IV-administered opiates once medically supervised withdrawal from an opiate agoinst has been achieved is the number one priority of the COMP. The number two priority of the COMP is to develop medications that will ameliorate the abstinence agony associated with opiate withdrawal. In particular, we are seeking medications with a low side effects profile, agents that affect both acute and protracted symptoms of opiate withdrawal and agents that ameliorate both the physical and psychological symptoms of opioid withdrawal. In the United States, the only FDAapproved medications for this indication is methadone, although alpha-2-adrenergic agonists are often used "off label" for this purpose. The number 3 priority of the COMP is to develop medications that can be coad- 
ministered with methadone gradually to decrease the dependence of the addicted individual to $m u$ opiate agonists and to help the individual achieve the transition from opiate agonist to opiate antagonist pharmacotherapy. Of priority for the indications of relapse prevention, opiate withdrawal reduction, and decreased dependency by coadministered nonopiate compounds is the development of nonopioid medications with little or no abuse liability. The drug classes discussed in this review (noncompetitive and competitive NMDA receptor antagonists, glycine antagonists, partial glycine agonists, and NOS inhibitors) all have a significant potential for the treatment of these novel medication indications for opiate addiction. Indeed even beyond opiate addiction, the efficacy of NMDA receptor antagonists in inhibiting cocaine self-administration in rats (Pulvirenti et al. 1992) and inhibiting the locomotor potentiating effects of cocaine (Pulvirenti et al. 1991) suggest that these agents show promise for the treatment of cocaine dependency as well.

\section{PHARMACOLOGICAL CLASSIFICATION OF NMDA RECEPTOR ANTAGONISTS}

Glutamate receptors are thought to be among the major excitatory neurotransmitter systems in mammalian brain. They are characterized by their molecular biology, pharmacology, and electrophysiology. The best-known of these receptor types are ionotropic or ligand-gated ion channels that are subtyped into three categories: alpha-amino-3-hydroxy-5-methyl-4 isoxazole propionate (AMPA), kainate (KA) receptors, and N-methyl D-aspartate (NMDA) receptors. More recently, metabotropic glutamate receptors have been identified (Sugiyama et al. 1987). (For a review of the molecular biology of the cloned glutamate receptors, see Hollmann et al. 1989; Boulter et al. 1990; Moriyoshi et al. 1991; Sommer and Seeburg 1992; Hollmann and Heinemann 1994).

Figure 1 provides a diagrammatic presentation of the NMDA ion-channel receptor complex and its modulatory sites. (See Palfreyman 1994 for a complete review of glutamate receptors and their regulators. Also see a review by Meldrum 1994 providing a summary of the pharmacology of the glutamate receptor subtypes and associated antagonists, which is in part summarized in brief below.) As described by Palfreyman (1994), activation of the NMDA receptor by glutamate (or NMDA) opens a cation-selective ion channel, and current only flows if the membrane is first depolarized and the $\mathrm{Mg}^{2++}$ block removed. The cation channel is readily permeable to calcium, sodium, and potassium, and the influx of any one of these activates the NMDA receptor. This activation may initiate prolonged changes in brain function associated with opiate addiction (tolerance, dependence, craving; see below).
The NMDA receptor requires activation via two agonist sites, one of which blinds glutamate and the other one of which binds glycine. Glycine is an obligate coagonist [i.e., activation of the NMDA receptor requires the simultaneous presence of glutamate and glycine (Johnson and Ascher 1987; Palfreyman 1994)].

There are four major types of NMDA receptor antagonists. Examples of each follow:

1. Noncompetitive NMDA receptor antagonists. phencyclidine (PCP), ketamine, MK801 (dizocilpine), dextrorphan, dextromethorphan, ADCI, FPL12495, CNS1102.

2. Competitive NMDA receptor antagonists. D-2amino-5phosphovalerate (AP5), 2-amino-7-phosponoheptanoate (AP7), LY274614, LY233536, LY233053, CGP40016, CGP43487, cis-4-(phosphonomethyl) piperidine-2-carboxylate (CGS19755) 3-(2 carboxypiperazine-4yl)-propylphosphonate $[\mathrm{D}(-) \mathrm{CPP}], \mathrm{D}(-)-$ CPPene.

3. Glycine site antagonists (see Baron et al. 1994). kynurenic acid, MDL28469, 5,7-DCKA, MDL 100748, MDL 29951, MDL 102288, MDL 100573, quinoxalinedione (e.g., ACEA-1328), DNXQ, 8-methyl-DDHB, L-689560 (tetrahydroquinolones), MDL 105572 (3Aryl-4-hydroxy-2-quinolones), 7-CKA, felbamate (Felbatol), ACPC (partial glycine agonist, see below).

4. Polyamine site antagonists (Scatton et al. 1994). Ifenprodil, eliprodil.

These pharmacological agents provide a rich array of drugs that can be used to address questions concerning the role of specific sites on the NMDA receptor and functions modulated by these receptors.

\section{EFFECTS OF NONCOMPETITIVE NMDA RECEPTOR ANTAGONISTS ON OPIOID TOLERANCE}

As shown in Table 1, to date there have been at least 17 investigations exploring the effects of the noncompetitive NMDA receptor antagonist MK801 (dizocilpine), in either morphine tolerance and/or morphine withdrawal in three murine species (guinea pigs, rats, mice). Each of the 10 studies examining the effects of MK801 on morphine tolerance have found that this drug inhibits the development of morphine tolerance, including eight studies in rats (Trujillo and Akil 1991a, 1994; Marek et al. 1991a, 1991b; Ben-Eliyahu et al. 1992; Bhargava and Matwyshyn 1993; Gutstein and Trujillo 1993; Tiseo and Inturrisi 1993) and two studies in mice (Lufty et al. 1993a; Elliott et al. 1994b). Each of these studies in rats have dissociated these effects of tolerance from analgesia itself, since the same MK801 dose does not appear to affect pain responsiveness itself (i.e., analgesic or hyperalgesic characteristics when administered 

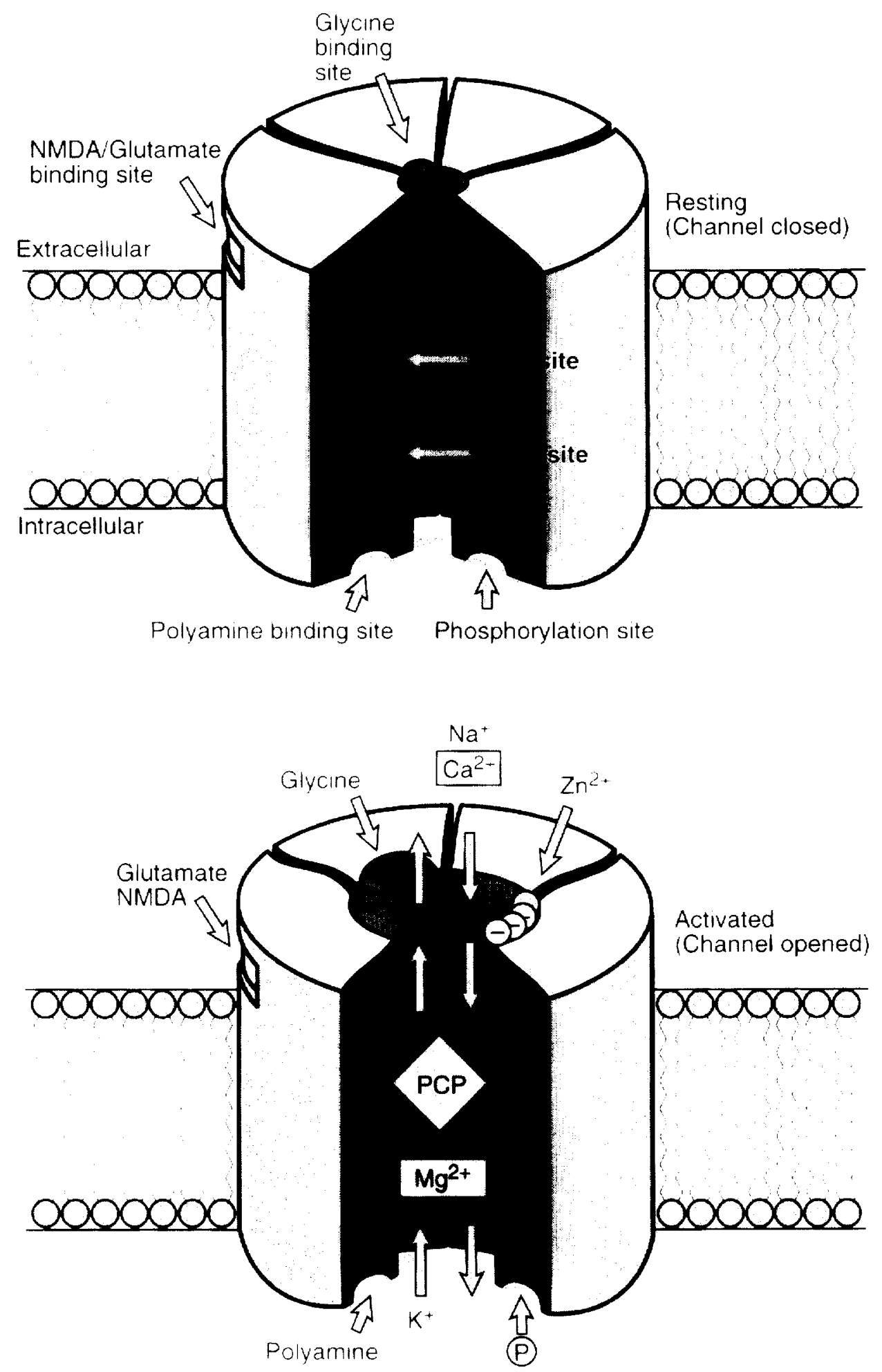

Figure 1. NMDA ionchannel receptor complex and its modulatory sites in the resting state (top) and in the open state (bottom). PCP $=$ phencyclidine. Source: Palfreyman MG, Glutamate receptors and their regulators-an overview. In Palfreyman MG, Reynolds IJ, Skolnick P (eds), Direct and allosteric control of glutamate receptors. Boca Raton, FL, CRC Press, 1994, Fig. 1.2. With permission of the author and the publisher. alone) or to influence the acute analgesic effects of morphine given as a single analgesic dose (Trujillo and Akil 1991a, 1994; Marek et al. 1991a, 1991b; Ben-Eliyahu et al. 1992; Bhargava and Matwyshyn 1993; Gutstein and Trujillo 1993; Tiseo and Inturrisi 1993). Similarly, MK801 when administered alone also does not appear to have nociceptive or antinociceptive effects in either Swiss
Webster mice (Lufty et al. 1993) or CD-1 mice (Elliott et al. 1994b). As indicated in Table 1, more studies are needed to determine whether MK801 is capable of reversing $m u$ opioid tolerance.

Trujillo and Akil (1991a) and Marek et al. (1991a, and 1991b) were among the first to demonstrate the capacity of MK801 to inhibit morphine tolerance in the 
rat (Trujillo et al. this volume). In the Trujillo and Akil (1991a) study this inhibition in tolerance was shown both during the period when MK801 was coadministered with morphine and during a 24-hour period subsequent to MK801 administration. Tolerance was induced by the BID administration of morphine $(10 \mathrm{mg} / \mathrm{kg}$ SC) for a period of 9 days, and analgesia was assessed with the radiant heat tail flick (TF) procedure. There were five major findings of this study. (1) MK801 was shown gradually to inhibit the development of morphine tolerance, with a significant inhibition of tolerance first emerging on days 5 through 9. (2) This effect of MK801 in inhibiting morphine tolerance was dose dependent and doses of $0.03 \mathrm{mg} / \mathrm{kg}$ MK801 were ineffective while doses of 0.1 or $0.3 \mathrm{mg} / \mathrm{kg}$ MK801 produced a significant inhibition of tolerance. (3) MK801 alone was found to have no analgesic effects when administered chronically in combination with saline or acutely immediately prior to morphine in doses from 0.1 to $0.3 \mathrm{mg} / \mathrm{kg}$, suggesting that the effects of MK801 cannot be explained by simple agonist or antagonist effects. (4) MK801 produced an inhibition in morphine tolerance that lasted at least 24 hours following the last chronic drug dose administration. This study demonstrated the potency of a noncompetitive NMDA receptor antagonist in inhibiting morphine tolerance in rats. and similar results were reported almost simultaneously by Marek et al. (1991a, 1991b).

A follow-up series of experiments were subsequently performed by Trujillo and Akil (1994) examining the effects of four noncompetitive NMDA receptor antagonists [MK801, phencyclidine (PCP), ketamine, and dextrorphan] on the inhibition of morphine tolerance in rats. There were five major findings. (1) All four noncompetitive NMDA receptor antagonists signifcantly inhibited morphine tolerance (produced by repeated injections or pellets of morphine). (2) PCP (1.0 $\mathrm{mg} / \mathrm{kg}$ IP) proved to be about 10 -fold less potent than MK801 $(0.1 \mathrm{mg} / \mathrm{kg} \mathrm{IP})$ in inducing these effects, corresponding to the relative potency of these noncompetitive NMDA receptor antagonists in in vitro investigations and to the relative affinities of these agents at the NMDA binding site. (3) An inhibition of morphine tolerance was produced by systemic osmotic minipump infusion of MK801 $(0.1 \mathrm{mg} / \mathrm{kg} /$ day $)$, PCP $(1.0 \mathrm{mg} / \mathrm{kg} /$ day $)$. dextrorphan $(5.0 \mathrm{mg} / \mathrm{kg} /$ day), and ketamine (10 $\mathrm{mg} / \mathrm{kg} /$ day) coadministered with morphine. These data indicate that the effects of NMDA receptor antagonists on morphine tolerance appear to reflect a fundamental change in nonassociative tolerance (i.e., they appear to be unrelated to conditioned cues associated with morphine administration). (4) The inhibition of morphine tolerance persisted for as long as 17 days in the absence of the continued administration of each of these four NMDA receptor antagonists. This indicates that these drugs induce a relatively permanent change in the pro- cess (not the expression) of $m u$ opioid tolerance itself (for noncompetitive drugs, see Trujillo and Akil 1991a; Ben-Eliyahu et al. 1992; for competitive drugs, see Tiseo and Inturrisi 1993). In support of this notion, Marek et al. (1991b) showed that MK801 could inhibit the development of morphine tolerance when administered repeatedly as long as 2 hours after each daily injection of morphine in rats. (5) A single injection of these four noncompetitive NMDA receptor antagonists failed to reverse already established morphine tolerance. These results differ markedly from the reversal in morphine tolerance obtained by Tiseo and Inturrisi (1993) using the potent competitive NMDA receptor antagonist LY274614 in rats and by Elliott et al. (1994a) using the noncompetitive NMDA receptor antagonist DM in mice. The reason for this difference across investigators may reflect the fact that Trujillo and Akil (1994) administered their NMDA receptor antagonists only once following the production of morphine tolerance, whereas both Tiseo and Inturrisi (1993) and Elliott et al. (1994b) administered their NMDA receptor antagonists daily for a number of days before reversal was achieved. This follow-up study by Trujillo and Akil (1994) provides evidence of the ubiquity of the inhibition of morphine tolerance produced by a number of different noncompetitive NMDA receptor antagonists.

There also appears to be some symptom specificity in this effect of MK801 in morphine tolerance: Not all morphine tolerance effects appear to be inhibited by MK801. For example, Bhargava and Matwyshyn (1993) reported that MK801 (0.03 to $0.3 \mathrm{mg} / \mathrm{kg}$, IP) inhibited the tolerance to the analgesic but not to the hyperthermic effects of morphine in rats. Finally, there is also some evidence that these effects may be modulated at the spinal levels. MK801 has been shown to inhibit the tolerance to the analgesic effects of morphine on the radiant heat $T F$ response in spinalized rats deprived of neural connections from the spine to higher brain centers (Gutstein and Trujillo 1993). Additional studies are needed in both rats and mice to determine whether MK801 and other noncompetitive NMDA receptor antagonists are capable of reversing morphine tolerance when already established. There appears to be only one out of the 17 studies using MK801 where the question of reversal of morphine tolerance has been investigated (Trujillo and Akil 1994). Given the highly significant effects of MK801 on the inhibition of morphine withdrawal symptoms in guinea pigs (see later), it would seem valuable for other investigators to study the effects of MK801 (at low doses) on morphine tolerance in guinea pigs. Such studies may afford a peek into the phylogeny of the MK801/morphine tolerance response. The usefulness of going beyond guinea pigs in higherorder species with MK801 testing is questionable given the high side effect profile of MK801 even in rats (see neurotoxicity section). These side effects include the en- 
Table 1. Effects of the Noncompetitive NMDA Receptor Antagonist MK801 on Mu (Morphine) Opioid Tolerance and Withdrawal

\begin{tabular}{|c|c|c|c|c|}
\hline Investigators & Species & $\begin{array}{l}\text { Inhibition of } \\
M u \text { Tolerance }\end{array}$ & $\begin{array}{c}\text { Reversal of } \\
M u \text { Tolerance }\end{array}$ & $\begin{array}{c}\text { Inhibition of } \\
M u \text { Withdrawal }\end{array}$ \\
\hline Tanganelli et al. (1991) & Guinea pigs & NT & NT & Yes \\
\hline Brent \& Chahl (1993) & Guinea pigs & NT & NT & Yes \\
\hline Trujillo \& Akil (1991a) & Rats & Yes & NT & Yes \\
\hline Rasmussen et al. (1991) & Rats & NT & NT & Yes \\
\hline Marek et al. (1991a) & Rats & Yes & NT & NT \\
\hline Marek et al. (1991b) & Rats & Yes & NT & NT \\
\hline Ben-Eliyahu et al. (1992) & Rats & Yes & NT & NT \\
\hline Tiseo \& Inturrisi (1993) & Rats & Yes & NT & NT \\
\hline Bhargava \& Matwyshyn (1993) & Rats & Yes & NT & NT \\
\hline Trujillo \& Akil (1994) & Rats & Yes & No & NT \\
\hline Gutstein \& Trujillo (1993) & Rats & Yes & NT & NT \\
\hline Marquis et al. (1991) & Mice & NT & NT & Yes/No \\
\hline Tanganelli et al. (1991) & Mice & NT & NT & Yes \\
\hline Matwyshyn et al. (1993) & Mice & NT & NT & No \\
\hline Lufty et al. (1993) & Mice & Yes & NT & NT \\
\hline Elliott et al. (1994b) & Mice & Yes & NT & NT \\
\hline Thorat et al. (1994) & Mice & NT & NT & No \\
\hline
\end{tabular}

NT $=$ not tested; $\left.N_{0}\right)=$ no significant effect; Yes $=$ significant effect: Yes $N_{0}=$ mixed effects

hancement of morphine lethality produced by MK801 (Trujillo and Akil 1991a, 1991b; Bhargava and Matwyshyn 1993), the phencyclidine (PCP)-like side effects of MK801 (Willetts et al. 1990; Rasmussen et al. 1991), and the formation of vacuoles in the cingulate and retrosplenial cortex produced by MK801 in rat brain (Olney et al. 1989, 1991; Auer and Coulter 1994), although not in squirrel monkey brain (Auer 1994).

The opioid receptor specificity for these effects of MK801 on $m u$ tolerance versus tolerance associated with other opioid receptor systems is not clear at this time (see Table 2). Whereas Bhargava and coinvestigators have reported that $\mathrm{MK} 801$ inhibits $k^{2}{ }^{2} a_{1}$ agonist (U50488H) analgesia (but not hyperthermia) tolerance in both rats (Bhargava 1994, 1995b; Bhargava et al. 1995b) and mice (Bhargava and Thorat 1994), Elliott et al. (1994b) failed to find a significant effect of MK801 on either $k a p p a_{1}(\mathrm{U} 50488 \mathrm{H})$ tolerance or kappa 3 agonist [naloxone benzoylhydrazone $(\mathrm{NalBzoH})$ ] tolerance in CD-1 mice. Further research is needed to clarify the effects of MK801 on both kappa ${ }_{1}$ and kappa $a_{3}$ tolerance to determine if this drug or other noncompetitive NMDA receptor antagonists influence delta tolerance and to determine whether the tolerance induced by delta or kappa receptor agonists can be "reversed" (not just inhibited) by noncompetitive NMDA receptor antagonists such as MK801.

Table 3 summarizes the effects of other noncompetitive NMDA receptor antagonists on morphine tolerance and opiate withdrawal. As shown, there have been at least five studies investigating the effects of DM, dextrorphan, $\mathrm{PCP}$, ketamine, and kynurenic acid on morphine tolerance in two murine species (rats and mice). The clinical utility of the DM data are particularly

Table 2. Effects of the Noncompetitive NMDA Receptor Antagonist MK801 on Kappa $(\mathrm{U} 50488 \mathrm{H})$ and Kappa 3 (NalBzoH) Opioid Tolerance and Withdrawal

\begin{tabular}{lcccc}
\hline \multicolumn{1}{c}{ Investigators } & $\begin{array}{c}\text { Species } \\
\text { Tested }\end{array}$ & $\begin{array}{c}\text { Inhibition of } \\
\text { Kappa }_{\mathbf{1}} \text { Tolerance }\end{array}$ & $\begin{array}{c}\text { Inhibition of } \\
\text { Kappa }_{3} \text { Tolerance }\end{array}$ & $\begin{array}{c}\text { Inhibition of } \\
\text { Kappa } \text { Withdrawal }\end{array}$ \\
\hline Bhargava (1994) & Rats & Yes & NT & NT \\
Bhargava et al. (1995b) & Rats & Yes & NT & NT \\
Bhargava (1995b) & Rats & Yes & NT & NT \\
Elliott et al. (1994b) & Mice & No & No & NT \\
Bhargava \& Thorat (1994) & Mice & Yes & NT & NT \\
\hline
\end{tabular}

NT $=$ not tested; $\quad V_{0}=$ no significant effect; $Y e s=$ significant effect 
Table 3. Effects of Other (Dextrorphan, Dextromethorphan, Phencyclidine, Ketamine, Kynurenic Acid) Noncompetitive NMDA Receptor Antagonists on $M u$ (Morphine) Opioid Tolerance and Withdrawal

\begin{tabular}{|c|c|c|c|c|c|}
\hline Drug Name & Investigators & Species & $\begin{array}{l}\text { Inhibition } \\
M u \text { Tolerance }\end{array}$ & $\begin{array}{c}\text { Reversal } \\
M u \text { Tolerance }\end{array}$ & $\begin{array}{c}\text { Inhibition } \\
M u \text { Withdrawal }\end{array}$ \\
\hline $\begin{array}{c}\text { Dextromethorphan } \\
+ \text { diazepam }+ \\
\text { chlorpromazine }\end{array}$ & $\begin{array}{l}\text { Koyancuoglu \& Saydam } \\
\quad(1990)\end{array}$ & Humans & NT & NT & Yes \\
\hline \multirow[t]{3}{*}{ Dextromethorphan } & Rosen et al. (1995) & Humans & VT & NT & No \\
\hline & Koyuncuoglu et al. (1990) & Rats & NT & NT & Yes \\
\hline & Elliott et al. (1994a) & Mice & Yes & Yes & NT \\
\hline Dextrorphan & Trujillo \& Akil (1994) & Rats & Yes & No & NT \\
\hline Phencyclidine & Trujillo \& Akil (1994) & Rats & Yes & No & NT \\
\hline \multirow[t]{3}{*}{ Ketamine } & Brent \& Chahl (1993) & Guinea pigs & NT & NT & Yes \\
\hline & Koyuncuoglu et al. (1990) & Rats & NT & NT & Yes \\
\hline & Trujillo \& Akil (1994) & Rats & Yes & No & NT \\
\hline Kynurenic acid & Marek et al. (1991b) & Rats & Yes & NT & NT \\
\hline
\end{tabular}

NT = not tested; No = no significant effect: Yes = significant effect

noteworthy and are discussed in greater detail in a later section. Elliott and coworkers (1994a, and this volume) demonstrated that DM is capable of both inhibiting and reversing morphine tolerance in mice. Antecedent administration of DM ( $30 \mathrm{mg} / \mathrm{kg} \mathrm{SC}$ ) compared to saline prevented the fivefold increase in the $\mathrm{ED}_{50}$ value to the analgesic effects (TF) of morphine in CD-1 mice exposed to escalating doses of morphine in a tolerance paradigm. Moreover, DM reversed the tolerance to the analgesic effect of 3 days of exposure to implanted morphine pellets, and the $\mathrm{ED}_{50}$ for the analgesic effects of morphine on TF were nearly equivalent to their saline control comparison group. Similarly, as indicated, Trujillo and Akil (1994) also reported that dextrorphan inhibited tolerance to the analgesic effects of morphine in rats. [DM is metabolized to dextrorphan in the rat (Zysset et al. 1988) but has a lower affinity for inhibiting $\left[{ }^{3} \mathrm{H}\right] \mathrm{MK} 801$ binding versus dextrorphan (Jaffe et al. 1989)]. In agreement with these findings, other noncompetitive NMDA receptor antagonists (PCP, ketamine, and kynurenic acid) have also been found to inhibit morphine tolerance in rats (Marek et al. 1991b; Trujillo and Akil 1994). As indicated in Table 3, more studies are needed to determine if these other noncompetitive NMDA receptor antagonists are capable of also reversing $m u$ opioid tolerance.

The biochemical mechanism underlying the inhibitory effect of competitive and noncompetitive NMDA receptor antagonists on morphine tolerance is unknown and will require much further research. Although the results of at least two studies suggest that these effects are not modulated through opioid receptors (Lufty et al. 1993; Tiseo et al. 1994), a preliminary report by Bhargava et al. (1995b) suggests the possibility that in the case of MK801 these effects may be modulated through kappa opioid receptors. The evidence that either non- competitive or competitive NMDA receptor antagonists fail to bind to any known opioid receptor includes the following. First, Lufty et al. (1993) have shown that MK801 is very poor at displacing $\left[{ }^{3} \mathrm{H}\right]$ naloxone and that it does this only in the $\mu \mathrm{M}$ range of a 1,000 -fold lower potency than either morphine or naloxone. Second, these investigators also found that naloxone, naltrexone, and morphine are also poor at displacing $\left[{ }^{3} \mathrm{H}\right] \mathrm{MK} 801$ binding sites at the NMDA receptor inophore complex (i.e., $\mu \mathrm{M}$ range). Third, as described in the sections that follow, Tiseo et al. (1994) have reported that chronic administration (at doses that inhibit morphine tolerance) of the competitive NMDA receptor antagonist LY274614 failed to result in changes in the affinity or binding of $m u$, delta, kappa $a_{1}$, or kappa $a_{3}$ opioid receptors in rat brain homogenate. In addition, LY274614, did not interfere either with the binding of selective opioid receptor subtypes at $m u_{1}, m u_{2}$, delta, $k a p p a_{1}$, or $k a p p a_{3}$, even at concentrations that are greater than $10 \mu \mathrm{M}$ (Tiseo et al. 1994). In contrast to these findings, the results of a recent preliminary report by Bhargava et al. (1995b) suggest that the effects of MK801 in inhibiting morphine tolerance may be modulated by alterations in kappa opioid receptors in rat brain. Specifically, Bhargava et al. (1995b) reported that MK801 inhibited the in vitro binding of $\left[{ }^{3} \mathrm{H}\right] \mathrm{EKC}$ (a kappa agonist) to both brain $(9.80 \mu \mathrm{M})$ and spinal cord membranes $(1.37 \mu \mathrm{M})$ in rats. In addition, Bhargava et al. (1995b) reported that chronic administration of MK801 resulted in an upregulation of kappa opioid receptors in brain. Further research is needed to clarify whether both noncompetitive or competitive NMDA receptor antagonists have their effects on morphine or kappa opioid tolerance through kappa opioid receptors. There is also evidence that these effects appear to relate to changes in glutamate, glycine, or some aspect of 
the NMDA receptor. For example, the binding of $\left[{ }^{3} \mathrm{H}\right] \mathrm{MK} 801$ is decreased in some brain regions in morphine-tolerant and -abstinent rats but only in the presence of glutamate and glycine (Gudehithlu et al. 1993; Bhargava 1994, 1995a) and only slightly in the cortex when these ligands are absent (Gudehithlu et al. 1994). Based on these data, Bhargava (1994) has suggested that endogenous glutamate and glycine may be altered following the activation of NMDA receptors in animals chronically treated with morphine.

Recent research from Mao et al. (1994) has indicated that the thermal hyperalgesia that develops in association with morphine tolerance in rats involves the coactivation of central NMDA and non-NMDA receptors. For example, coadministration of intrathecal morphine with MK801 prevented the development of this hyperalgesia. The authors suggest that these results may have implications for the treatment of painful conditions such as neuropathic pain, postoperative pain, and cancer pain. Similarly, an earlier study by Mao et al. (1992) indicated that intrathecal MK801 and local nerve anesthesia synergistically reduce the hyperalgesia shown in rats with experimental peripheral mononeuropathy. [Further details on these studies and an update on the influence of DM on neuropathic pain was provided by Mayer (1995) for this technical review].

It is yet unexplained why even though acute administration of MK801 does not appear to potentiate the analgesic effects of morphine in rodents (Trujillo and Akil 1991a, 1994), it does potentiate the capacity of morphine to induce both catalespy and lethality (e.g. Trujillo and Akil 1991b). It is not known whether other noncompetitive or competitive NMDA receptor antagonists influence these other important side effects of morphine. The clinical relevance of this is that if a NMDA receptor antagonist inhibits the development of morphine tolerance, it might also alter the side effects of $m u$ opiates, including their motor and respiratory effects. This question needs to be carefully evaluated in nrerlinical stridies

\section{EFFECTS OF NONCOMPETITIVE NMDA RECEPTOR ANTAGONISTS ON OPIOID WITHDRAWAL}

Table 1 indicates that there has been at least a total of eight investigations examining the effects of MK801 on the naloxone-induced withdrawal symptoms associated with chronic morphine administration in three murine species. The evidence to date suggests that MK801 is capable of significantly inhibiting morphine withdrawal symptoms in guinea pigs (Tanganelli et al. 1991; Brent and Chahl 1993) and in rats (Rasmussen et al. 1991. Trujillo and Akil 1991a; Rasmussen this volume; Trujillo this volume). More controversial are the effects of MK801 in inhibiting morphine withdrawal symptoms in mice because there has been one investigation of significant effects (Tanganelli et al. 1991), one preliminary report of mixed results (Marquis et al. 1991) and two investigations that failed to obtain significant effects (Matwyshyn et al. 1993; Thorat et al. 1994). Additional investigations will be needed to clarify the discrepancy in results of MK801 and opiate withdrawal in mice. However, the MK801 effects do not appear to be as robust or as easily replicated as the effects of NMDA receptor antagonists on the inhibition of morphine tolerance in this species.

As noted in Table 1, there have been at least two positive reports of MK801 inhibiting opiate withdrawal symptoms in guinea pigs (Tanganelli et al. 1991; Brent and Chahl 1993), and these effects are of particular interest considering that guinea pigs have a more evolved brain than either rats or mice. Tanganelli et al. (1991) examined the effects of MK801 (1 mg/kg IP) on naloxone-precipitated ( $3 \mathrm{mg} / \mathrm{kg}$ IP) opiate withdrawal in guinea pigs. Results indicated that MK801 decreased narcotic antagonist-precipitated hyperactivity (jumping, exploration, wet dog shakes) and the threefold increase in cortical acetylcholine ( $\mathrm{ACh}$ ) produced by naloxone. Brent and Chahl (1993) conducted a series of studies on the effects of the inactive enantiomer of $(-) \mathrm{MK} 801(1.0 \mathrm{mg} / \mathrm{kg} \mathrm{SC})$, the active enantiomer of (+)MK801 $(0.025,0.1$, and $1.0 \mathrm{mg} / \mathrm{kg} \mathrm{SC})$, and ketamine (20 mg/kg SC) (Table 3) on naloxone-precipitated (15 $\mathrm{mg} / \mathrm{kg}, \mathrm{SC})$ opiate [single dose of morphine $(15 \mathrm{mg} / \mathrm{kg}$ SC)] withdrawal in guinea pigs. Dependent measures included effects on spontaneous locomotor activity and on the frequency of qualitative measures of opiate withdrawal. In animals treated with morphine alone, naloxone induced about a 20 -fold increase in spontaneous locomotor activity. As expected, (-)MK801 had no significant effects. Although the two highest doses of MK801 completely abolished both the naloxoneinduced hyperactivity and virtually all of the motor withdrawal behaviors, these effects were difficult to interpret because these doses also induced a large degree of motor impairment and ataxia. However, the lowest dose of MK801 $(0.025 \mathrm{mg} / \mathrm{kg})$ induced no motor abnormalities, but it induced dramatic decreases in naloxoneinduced hyperactivity as well as decreases in many of the motor withdrawal behaviors. The effects of ketamine $(20 \mathrm{mg} / \mathrm{kg} \mathrm{SC}$ were difficult to interpret because although this dose decreased withdrawal behavior it also induced a marked degree of ataxia. These results underscore the importance of including careful doseresponse profiles of MK801 in opioid withdrawal studies and indicate that a dissociation can be achieved in the capacity of this noncompetitive NMDA receptor antagonist to inhibit opioid withdrawal versus inducing motoric PCP-like side effects.

A component of the experiment by Trujillo and Akil (1991a) involved the assessment of MK801 on naloxone- 
precipitated opiate withdrawal in rats. After administering morphine chronically for 9 days and conducting the TF test on day 10, these investigators precipitated opiate withdrawal with naloxone $(2 \mathrm{mg} / \mathrm{kg} \mathrm{SC})$. Effects were assessed on the frequency of escape jumps. Large numbers of escape jumps were produced by naloxone in the group that had received just chronic morphine and saline, whereas the pretreatment of MK801 throughout the morphine administration was associated with a nonsignificant increase in escape jumps (compared with control). The effects observed did not appear to reflect the influence of MK801 on the "expression" of opiate withdrawal symptoms because MK801 was discontinued for 24 hours before the test on day 10 was run. Therefore, these results indicate that MK801 inhibited the development of opiate withdrawal symptoms in rats, including the "hyperactivity" of opiate withdrawal.

During the same year Rasmussen et al. (1991) also reported that MK801 inhibited narcotic antagonistinduced morphine withdrawal in rats (Rasmussen et al. this volume). Dependence was produced by implanting two morphine pellets for 2 days, and 2 to 3 hours following this procedure withdraw al was precipitated with naltrexone. MK801 $(0.1$ and $1.0 \mathrm{mg} / \mathrm{kg})$ was given prior to the naltrexone. Results indicated that these doses of MK801 significantly suppressed a number of withdrawal behaviors, including teeth chattering, erections, ptosis, chewing action, wet dog shakes, lacrimation, weight loss, and diarrhea, but no significant effects were obtained on jumping, writhes, or salivation, and other withdrawal symptoms were intensified. How'ever, these MK801 effects were difficult to interpret (especially at the highest dose) because MK801 pretreatment produced a dose-related appearance of PCP-like motor dysfunctions, including falling, hyperkinetic locomotion, and weaving. [The reason for the discrepancy in the specific type of withdrawal symptoms decreased by MK801 in the Trujillo and Akil (1991a) study (i.e., the finding that narcotic antagonist precipitated jumping) versus the Rasmussen et al. (1991) study is unknown but may relate to the lack of effects for this measure reported in mice, as stated below 1 .

There may be genetic differences in the effects of MK801 in mice, as a report by Thorat et al. (1994) failed to find significant effects of MK801 on narcotic antagonist-precipitated withdrawal in morphine dependent mice (see also preliminary report of no effect by Matwyshyn et al. (1993)]. Indeed, a preliminary report by Marquis et al. (1991) indicated that acute administration of MK801 $(0.1 \mathrm{mg} / \mathrm{kg})$ significantly reduced the number of naloxone-precipitated jumps in morphinedependent mice (morphine pellets) when a lower dose $(0.05 \mathrm{mg} / \mathrm{kg}$ IP) but not when a higher dose $(0.1 \mathrm{mg} / \mathrm{kg}$ IP) of naloxone was used. Similarly, Marquis et al. (1991) found that in mice rendered tolerant by repeated injec- tion of morphine $(10 \mathrm{mg} / \mathrm{kg} \mathrm{SC})$, acutely administered MK801 (0.17 mg/kg IP) also significantly reduced naloxone-precipitated $(1.0 \mathrm{mg} / \mathrm{kg}$ IP) jumping. In contrast, in line with the findings of Thorat et al. (1994) and of Matwyshyn et al. (1993), Marquis et al. (1991) failed to obtain a significant effect of chronic coadministration of MK801 with morphine on naloxone-precipitated jumping, suggesting that the effects of MK801 on morphine dependency may also depend on the intensity of the opiate withdrawal reaction produced.

Other than MK801, a variety of other noncompetitive NMDA receptor antagonists have been evaluated for their capacity to inhibit morphine withdrawal. This includes at least three studies using DM, including two in humans (Koyuncuoglu and Saydam 1990; Rosen et al. 1995, presented at this review, manuscript in preparation), and one in rats (Koyuncuoglu et al. 1990) and two studies with ketamine, including one in guinea pigs (Brent and Chahl 1993, discussed above) and one in rats (Koyuncuoglu et al. 1990; see Table 3). DM holds particular interest because it is clinically available, has shown little history of dependence liability, is bioavailable when given orally, and has proved safe to the point that it is marketed on a nonprescription basis. (For further exploration of DM and opiate addiction, see Elliott et al. this volume). In addition to its over-the-counter use as an antitussive, DM has been evaluated in pilot studies in humans for Parkinson's disease (Bonuccelli et al. 1992; Saenz et al. 1993), intractable seizures (Fisher et al. 1990; Schmitt et al. 1993), and in patients at risk for cerebral ischemia (Albers et al. 1991). DM is believed to modulate its effects on opiate withdrawal by antagonizing the NMDA receptor, although it appears that DM may act as both a noncompetitive and competitive NMDA receptor antagonist (Jaffe et al. 1989; Netzer et al. 1993)

Koyuncuoglu et al. (1990) examined the effects of $\mathrm{DM}(1$ or $2 \mathrm{mg} / \mathrm{kg})$ and ketamine $(0.5$ or $1.0 \mathrm{mg} / \mathrm{kg})$ on naloxone-precipitated $(2.0 \mathrm{mg} / \mathrm{kg}$ IP) opiate withdrawal in rats. Dependence was produced by subcutaneous implantation of three pellets of $75 \mathrm{mg}$ of morphine (225 $\mathrm{mg}$ total). After 3 days of morphine exposure, the rats were divided into appropriate control and drug treatment groups. DM or ketamine were given just before naloxone administration. The $1.0-\mathrm{mg} / \mathrm{kg}$ DM dose induced a partial, although significant, suppression in some opiate withdrawal responses (e.g., flying, teeth chattering), and the $2.0-\mathrm{mg} / \mathrm{kg}$ DM dose induced a nearcomplete suppression in all of the naloxone-precipiated withdrawal symptoms, including flying, jumping, teeth chattering, wet dog shakes, defecation, diarrhea, and ptosis. For ketamine, no significant effects were obtained for the low dose, but a significant suppression in some of the withdrawal symptoms was produced by the $1.0-\mathrm{mg} / \mathrm{kg}$ dose. Thus, these data suggest that a single administration of a low dose of DM minutes before 
naloxone administration can inhibit morphine withdrawal symptoms in rats. There is an obvious need to attempt replication of this study in rats and in other murine species and in nonhuman and human primates if these other animal studies prove positive.

Based in part on animal modeling data, at least two groups of investigators have assessed the potential utility of DM for the treatment of opioid withdrawal in humans. Koyuncuoglu and Saydam (1990) treated 48 heroin addicts ( 44 males, 4 females) in a double-blind design. All participants received diazepam (DZ $10 \mathrm{mg}$, every 6 hours). One DZ-treated group also received DM (15 mg, hourly, DM + DZ), and the other DZ-treated group received chlorpromazine $(4 \mathrm{mg}$, hourly; $\mathrm{CPZ}+$ $D Z$ ). There were no group differences with regard to gender, age, length or route of heroin dependency, or reported amounts of heroin used. Retention in the two groups varied. The $\mathrm{CPZ}+\mathrm{DZ}$ group had 15 dropouts on day 1 compared to 1 dropout for the $D M+D Z$ group on the same day. Overall, there were 21/21 early terminations in the $C P Z+D Z$ group, and $10 / 27$ early terminations in the $D M+D Z$ group. It is difficult to interpret the results of this study because of the use of adjunct medications, the considerable dropout rate within one arm of this study, and the baseline differences between the two groups for signs of withdrawal (the $\mathrm{CPZ}+\mathrm{DZ}$ group was significantly more symptomatic than the DM + DZ group on 5 of the 15 symptoms of withdrawal that were evaluated).

In another study reported by Rosen and colleagues (1995) a double-blind, placebo-controlled design using a dose-escalating procedure failed to find a significant effect for DM in preventing or attenuating naloxoneprecipitated withdrawal. Doses used were comparable with those in the Koyuncuoglu and Saydam (1990) study. Even though naloxone-precipitated withdrawal may not be equivalent to gradual withdrawal of an opioid agonist, three subjects in the Rosen sample underwent medically supervised withdrawal from methadone while receiving $60 \mathrm{mg}$ of DM every 4 hours. Two of these three participants experienced withdrawal symptoms although there was no comparison group. Clearly, additional studies will be needed to determine the efficacy of DM alone or coadministered with morphine in the alleviation of opioid withdrawal symptoms in humans.

\section{COMPETITIVE NMDA RECEPTOR ANTAGONISTS AND OPIOID TOLERANCE}

A second category of drugs that have been shown to effect opioid withdrawal are the competitive NMDA receptor antagonists that inhibit the binding of glutamate at the glutamate recognition site of the NMDA receptor (Ornstein et al. 1990; Rasmussen et al. 1991; Schoepp et al. 1991). By comparison, noncompetitive NMDA receptor antagonists are thought to act by blocking the ion channel for this receptor complex (Wong and Kemp 1991). Although both noncompetitive and competitive NMDA receptor antagonists block the NMDA receptor complex it is thought that the specific site where this takes place is different for noncompetitive versus competitive antagonists.

This difference in action between noncompetitive as compared with competitive NMDA receptor antagonists may have important implications for the relative capacity of these agents to induce PCP-like side effects, and generalizations concerning this type of side effect have limited the clinical development of this class of drugs. Unlike noncompetitive antagonists such as MK801, the competitive NMDA antagonists do not appear to substitute for $\mathrm{PCP}$ in drug discrimination procedures and generally do not produce PCP-like behaviors at convulsant doses (Willetts et al. 1990). One of the most potent competitive NMDA receptor antagonists is LY274614 (Schoepp et al. 1991). In support of the findings of Willetts et al. (1990), Rasmussen et al. (1991) have shown that in contrast with MK801, LY274614 does not produce the motor dysfunctions (head weaving, increased locomotion, falling) associated with PCP in rats. In contrast with the motor hyperactivity associated with PCP-like drugs and noncompetitive NMDA receptor antagonists, competitive NMDA receptor antagonists such as LY274614 induce mild to moderate sedation (Rasmussen et al. 1991). This argues for the possibility of a more important role for competitive versus noncompetitive NMDA receptor antagonists in clinical applications for opiate addiction (although see results of preclinical and preliminary human studies earlier in this article, including the effects of low-affinity noncompetitive NMDA receptor antagonists such as DM). For humans the dose of a competitive NMDA receptor antagonist required to affect opiate addiction phenomena may be lower than the dose found to induce PCP-like side effects, whereas for certain noncompetitive NMDA receptor antagonists the therapeutic window may be very narrow. This important hypothesis remains to be tested.

A summary of the effects of competitive NMDA receptor antagonists in inhibiting and/or reversing $m u$ and kappa opioid tolerance and withdrawal is shown in Table 4. Note that the most replicated finding to date is that competitive NMDA receptor antagonists are capable of inhibiting $m u$ opioid tolerance in murine species [5/5 reports of significant effects; for LY274614 see Tiseo and Inturrisi (1993); Tiseo et al. (1994) in rats, and Elliott et al. (1994b) in mice; for NPC17742 see Kolesnikov et al. (1993a) in mice; for LY235959 see Matwyshyn and Bhargava (1995) in mice], although there 
Table 4. Effects of Competitive NMDA Receptor Antagonists on $\mathrm{Mu}$ (Morphine), Kappa $\mathbf{1}_{1}\left(\mathrm{U} 50488 \mathrm{H}\right.$ ), and $\mathrm{Kappa}_{3}$ (NalBzoH) Opioid Tolerance and Withdrawal

\begin{tabular}{|c|c|c|c|c|c|}
\hline Drug Name & Investigators & $\begin{array}{l}\text { Species } \\
\text { Tested }\end{array}$ & $\begin{array}{l}\text { Inhibition of } \\
M u \text { Tolerance }\end{array}$ & $\begin{array}{c}\text { Reversal of } \\
M u \text { Tolerance }\end{array}$ & $\begin{array}{l}\text { Inhibition of } \\
M u \text { Withdrawal }\end{array}$ \\
\hline \multirow[t]{4}{*}{ LY274614 } & Rasmussen et al. (1991) & Rats & NT & NT & Yes \\
\hline & Tiseo \& Inturrisi (1993) & Rats & Yes & Yes & NT \\
\hline & Tiseo et al. (1994) & Rats & Yes & NT & NT \\
\hline & Elliott et al. (1994b) & Mice & Yes & NT & NT \\
\hline NPC17742 & Kolesnikov et al. (1993a) & Mice & Yes & NT & NT \\
\hline \multirow[t]{2}{*}{ LY235959 } & $\begin{array}{l}\text { Matwyshyn \& Bhargava } \\
\text { (1995) }\end{array}$ & Mice & Yes & NT & No \\
\hline & & & $\begin{array}{c}\text { Inhibition of } \\
K a p p a_{1} \text { Tolerance }\end{array}$ & $\begin{array}{c}\text { Inhibition of } \\
\operatorname{Kappa}_{3} \text { Tolerance }\end{array}$ & $\begin{array}{c}\text { Inhibition of } \\
\text { Kappa Withdrawal }\end{array}$ \\
\hline \multirow[t]{4}{*}{ LY274614 } & Rasmussen et al. (1991) & Rats & NT & NT & NT \\
\hline & Tiseo \& Inturrisi (1993) & Rats & NT & NT & NT \\
\hline & Tiseo et al. (1994) & Rats & NT & NT & NT \\
\hline & Elliott et al. (1994b) & Mice & No & No & NT \\
\hline NPC17742 & Kolesnikov et al. (1993a) & Mice & Yes & No & NT \\
\hline LY235959 & Thorat \& Bhargava (1995) & Mice & Yes & NT & NT \\
\hline
\end{tabular}

NT = not tested; $N_{0}=$ no significant effect; Yes $=$ significant effect

have been few attempts to determine whether these agents can reverse $m u$ opioid tolerance (Tiseo and Inturrisi 1993) or influence the expression of $m u$ opiate withdrawal symptoms [two reports, one significant (Rasmussen et al. 1991) in mice, one nonsignificant (Matwyshyn and Bhargava 1995) in mice]. There have been few studies on the effects of competitive NMDA receptor antagonists on kappa opioid tolerance; two indicated significant inhibition on tolerance (Kolesnikov et al. 1993a in mice; Thorat and Bhargava 1995 in mice) and the third was nonsignificant (Elliott et al. 1994b in mice). Therefore, additional research is needed to determine the specificity of these results to other opioid receptors, including the delta and kappa type.

Tiseo and Inturrisi (1993) conducted the first series of experiments demonstrating that the competitive NMDA receptor antagonist LY274614 inhibits morphine tolerance in rats (Elliott et al. this volume; see also Tiseo et al. 1994). Even more noteworthy, these researchers showed for the first time that both competitive (i.e., LY274614) and noncompetitive (MK801) NMDA receptor antagonists could reverse morphine tolerance after it had been established. These former results appear to extend to other murine species, including mice. For example, competitive NMDA receptor antagonists have been shown to inhibit morphine tolerance in CD-1 mice in an investigation by Elliott et al. (1994b) using LY274614, in a second investigation by Kolesnikov et al. (1993a), using NPC17742 and CD-1 mice and in a recent investigation by Matwyshyn and Bhargava (1995) using LY235959 (the active isomer of LY274614) and Swiss Webster mice. Furthermore, this effect of com- petitive NMDA receptor antagonists may be opioidreceptor specific as both of these latter sets of investigators failed to find a significant effect of competitive NMDA receptor antagonists in inhibiting the development of $\mathrm{kappa}_{3}$ opioid receptor tolerance using the opioid agonist drug naloxone benzoylhydrazone (NalBzoH) (Kolesnikov et al. 1993a; Elliott et al. 1994b). The effects of competitive NMDA receptor antagonists on kappa $_{i}$ opioid receptor tolerance using the opioid agonist U50488H have been examined in three studies, and significant inhibition of tolerance for this agent was obtained by Kolesnikov et al. (1993a) using NPC17742 and by Thorat and Bhargava (1995) using LY235959, whereas no significant effects of LY274614 were detected by Elliott et al. (1994b).

Review of the Tiseo and Inturrisi (1993) findings is instructive for providing a template for this type of design for other researchers and for noting the power and limitations of competitive NMDA receptor antagonists in inhibiting $m u$ opioid receptor tolerance in rats. The hot plate (HP) procedure was used to evaluate analgesia. Tolerance was produced by BID injections of morphine (10 mg $/ \mathrm{kg} \mathrm{SC}$ ) given daily for 6 to 10 days depending on the experiment. The efficacy of LY274614 $(24 \mathrm{mg} / \mathrm{kg} / 24 \mathrm{~h}$ ) or of MK801 $(0.4 \mathrm{mg} / \mathrm{kg} 24 \mathrm{~h})$ delivered via osmotic minipumps was compared. This study demonstrated three major effects of LY274614. (1) LY274614 as well as MK801 attenuated the development of tolerance when coadministered with morphine, and this inhibition of tolerance (and the retention of analgesic sensitivity to morphine) persisted for at least 7 days in the absence of continued administration of 
drug. (2) Subsequent administration of LY274614 reversed $m u$ opioid receptor tolerance if administered to already morphine-tolerant animals. Indeed, rats receiving LY274614 for 1 week following the establishment of morphine tolerance (threefold dose-response shift) showed a virtually complete return in sensitivity to the analgesic effects of morphine. (3) Concurrent administration of LY274614 reversed morphine tolerance, and the reversal of tolerance persisted for at least 7 days after the cessation of LY274614. An important control was that neither LY274614 nor MK801 administered alone had significant analgesic effects, indicating that the NMDA receptor antagonists affected tolerance but not analgesia. In summary, the findings of Tiseo and Inturrisi (1993) suggested a unique and a specific role of NMDA receptor antagonists in opiate tolerance.

What are the differences between the inhibition and reversal of morphine tolerance produce by NMDA receptor antagonists compared with other drugs? [Note that some of these differences have been described by Tiseo and Inturrisi (1993)]. One difference is that the NMDA receptor antagonists appear to influence the "process" of tolerance itself rather than its "expression." This does not appear to be the case for other agents such as the cholecystokinin (CCK) antagonists. For example, the reversal of morphine tolerance by proglumide (a weak and nonselective CCK antagonist) has been reported to be immediate (Watkins et al. 1984), suggesting an influence in the "expression" of tolerance whereas the reversal of morphine tolerance by LY274614 takes place over a number of days (Tiseo and Inturrisi 1993), suggesting an influence in the "process" of tolerance itself. The fact that the reversal achieved by LY274614 is not immediate indicates that the NMDA receptor is probably not involved in the final step in the elaboration of morphine tolerance. In addition, another difference between NMDA receptor antagonists and CCK antagonists is that CCK antagonists potentiate morphine analgesia (Watkins et al. 1984; Dourish et al. 1988, 1990; O'Neill et al. 1989), making it difficult to differentiate an additive effect of analgesia alone on tolerance assessments in these studies. This difference is in marked contrast with the NMDA receptor antagonists that do not potentiate morphine analgesia (see below).

Second, unlike other drugs (e.g., narcotic antagonists), pharmacological evidence suggests that this effect of NMDA receptor antagonists on morphine tolerance does not reflect a simple antagonism of any of the known opioid receptors. Using behavioral pharmacological approaches, several investigators have shown that NMDA receptor antagonists inhibit morphine tolerance without antagonizing the analgesic effects of morphine (for noncompetitive NMDA receptor antagonists, see Marek et al. 1991a, 1991b; Trujillo and Akil 1991;
Ben-Eliyahu 1992; for competitive NMDA receptor antagonists, see Tiseo and Inturrisi 1993; Kolesnikov et al. 1993a; Elliott et al. 1994a; Tiseo et al. 1994). This contrasts with the effects of opiate receptor antagonists, which attenuate morphine tolerance only at doses that also block morphine analgesia. This includes narcotic antagonists that block $m u$, delta, and kappa opiate receptors such as naloxone (Mushlin and Cochin 1976; Smits 1976; Tremblay et al. 1976; Yano and Takemori 1977) and naltrexone (Bhargava 1978, 1994; Bhargava et al. 1994) and specific opiate receptor antagonists such as B-funaltrexamine (highly selective $m u$ opioid receptor antagonist; see Aceto et al. 1986). There are some biochemical data suggesting that the NMDA receptor antagonists do not directly compete with any known opioid receptor (e.g., Lufty et al. 1993; Tiseo et al. 1994; but see Bhargava et al. 1995b for effects on kappa opioid receptors) and do not alter the affinity or numbers of opioid receptors (Tiseo et al. 1994; but see Bhargava et al. 1995b for effects on kappa opioid receptors). Thus, the molecular mechanisms underlying the inhibition of morphine tolerance by LY274614 is unknown at this time, and much further research will be needed to clarify its biochemical basis. However, it does not appear to reflect a simple antagonism or change in $m u$ brain opioid receptors.

A third characteristic that differentiates the NMDA receptor antagonists from other agents in the inhibition of morphine tolerance is that the effect outlasts the coadministration period for several days. Coadministration of other agents have also been shown to inhibit morphine tolerance without influencing morphine's analgesic effects. These agents include systemically administered dynorphin A (1-13) or various Des-Tyr ${ }^{1}$ nonopioid fragments of dynorphin A (Tulunay et al. 1981; Takemori et al. 1992, 1993). However, unlike the delta opioid antagonists or the dynorphin A fragments, the NMDA receptor antagonists appear to be unique in producing a reversal of morphine tolerance that outlasts the coadministration period. This has important clinical implications, and further preclinical studies are needed to document the specific noncompetitive and competitive NMDA receptor antagonists that are capable of reversing, not just inhibiting, morphine tolerance. Additional studies are also needed to determine the longevity of the reversal in morphine tolerance produced by the NMDA receptor antagonists.

\section{COMPETITIVE NMDA RECEPTOR ANTAGONIST AND OPIOID WITHDRAWAL}

The effects of LY274614 as compared with MK801 on inhibiting naltrexone-induced withdrawal symptoms in morphine-dependent rats have been investigated by Rasmussen et al. (1991). (See Rasmussen in this vol- 
ume for further details and for a research update.) Pretreatment with LY274614 (50 and $100 \mathrm{mg} / \mathrm{kg}$ IP) or MK801 (0.1 and $1.0 \mathrm{mg} / \mathrm{kg} \mathrm{SC)} \mathrm{significantly} \mathrm{decreased}$ a number of opiate withdrawal symptoms, including teeth chattering, chewing action, ptosis, erections, diarrhea, and weight loss. However, both LY274614 and MK801 failed to affect significantly jumping, writhes, and salivation. The lack of effect of competitive NMDA receptor antagonists on narcotic antagonist-provoked opiate withdrawal "jumping" is notable and may indicate that this class of drugs have limited clinical potential for treating the "hyperactivity" versus gastroenterological (e.g., weight loss) elements of opiate withdrawal. Indeed, as shown in Table 4, a recent investigation by Matwyshyn and Bhargava (1995) has failed to find a significant effect of the competitive NMDA receptor antagonist, LY235959 on naltrexone-precipitated withdrawal from morphine.

Rasmussen and co-workers (1991 and this volume) have attempted to delineate the neuroanatomical/neurochemical substrate for this effect by recording cellular activity in the locus coeruleus (LC). As previously documented (Aghajanian 1978; Rasmussen et al. 1990), increased firing was produced in the cells of the LC as a consequence of narcotic antagonist administration in the opiate-dependent rat. However, unlike the inhibition in the behavioral symptoms of opioid withdrawal, LY274614 failed to inhibit this increased LC firing. An earlier study by Rasmussen and Aghajanian (1989) had indicated that intracerebroventricular injections of the nonspecific excitatory amino acid (EAA) antagonist (also glycine antagonist), kynurenic acid, inhibited naloxoneprecipitated LC opioid withdrawal. In addition, Akaoka and Aston-Jones (1991) reported that an inhibition in naloxone-induced increases in LC firing rate of the morphine-dependent rat could be produced by a number of NMDA receptor antagonist, including kynureate (nonspecific NMDA receptor and glycine antagonist), 6-cyano-7-dinitroquinoxaline -2,3-dione [CNQX; (nonNMDA receptor antagonists and a glycine antagonist)], and AP5 (competitive NMDA receptor antagonist). Interestingly, in the Akaoka and AstonJones (1991) study, AP5 was the least effective NMDA antagonist, suggesting, in combination with the findings of Rasmussen et al. (1991), that competitive NMDA receptor antagonists do not appear to be as effective as noncompetitive NMDA receptor antagonists in inhibiting naloxone-precipitated opioid withdrawal LC firing. The results of the Akaoka and Aston-Jones (1991) study indicate that a substantial component of the LC hyperactivity occurring during narcotic antagonist-induced opioid withdrawal is mediated by an augmented glutamatergic input to the LC that can be blocked by brain injections of noncompetitive NMDA or glycine receptor antagonists. More preclinical studies examining the behavioral and electrophysio- logical effects of competitive and noncompetitive NMDA receptor antagonists and glycine antagonists on opiate withdrawal are needed to determine the reliability of this finding across different drugs of these classes and different species.

\section{EFFECTS OF NMDA RECEPTOR ANTAGONISTS ACTING AS AGONISTS OR ANTAGONISTS AT THE GLYCINE SITE OF THE NMDA-RC ON OPIOID TOLERANCE AND WITHDRAWAL}

A group of NMDA receptor antagonists with possible clinical potential for the treatment of opiate addiction comprise agents that act as partial glycine site agonists at the strychnine-insensitive glycine site of the NMDA$R C$, including I-aminocyclopanecarboxylic acid (ACPC), D-cycloserine, 3-amino-I-hydroxypyrrolid-z-oe (HA966), or as antagonists at the glycine site, including I-amino-cyclobutylcarboxylic acid (ACBC), 7-chlorokynureate, 5-nitro-6,7-dimethyl-1,4-dihydro-2,3-quinoxalinedione (ACEA-1328), felbamate (Felbatol) and memantine (Foster and Kemp 1988; Huettner 1989; Marvizón et al. 1989; Hood et al. 1989, 1990, 1992; Watson and Lanthorn 1990; Baron et al. 1994; Boje 1994; Lufty et al. 1995). The glycine antagonists are agents that prevent glycine from binding to the glycine regulatory site of the NMDA receptor (Johnson and Ascher 1987; Williams et al. 1991), and these agents effectively prevent glutamate from activating the NMDA-RC because the glycine site acts as a coagonist site with the glutamate binding site. Unlike some noncompetitive NMDA receptor antagonists, the glycine site antagonists do not show discriminative generalization to PCP (Singh et al. 1990) or produce PCP-like motor effects in rodents (Koek and Colpaert 1990).

Kolesnikov et al. (1994) recently reported that the partial glycine agonist $\mathrm{ACPC}$ prevented tolerance to a $m u$ opioid agonist (morphine) and to a delta opioid agonist [D-Pen2,D-Pen5] enkephalin (DPDPE) when coadministered with either of these opioids in CD-1 mice. In addition, $A C P C$ reversed morphine tolerance. ACPC did not significantly inhibit tolerance to either a $k a p p a_{1}$ opioid $(\mathrm{U} 50,488 \mathrm{H})$ or a $k a p p a_{3}$ opioid (NalB$z \mathrm{OH})$. ACPC had no analgesic effects when given alone. Thus, these effects parallel the influence of the NMDA receptor antagonists and NOS inhibitors on $m u$ and kappa opioid tolerance obtained by these investigators in other studies (Kolesnikov et al. 1993a and 1993b; Babey et al. 1994). As noted by the authors, ACPC has promising clinical potential because it appears relatively free of side effects and has a number of other potentially positive effects in rodents such as acting as both an antidepressant and anxiolytic in appropriate animal models (Trullas et al. 1991). Similarly, Lufty et al. (1995) recently reported that ACEA-1328, a novel NMDA receptor/glycine site antagonist, inhibited morphine 
tolerance in mice without affecting the basal nociceptive response.

Kosten et al. (this volume) has found that felbamate significantly decreased the severity of opioid withdrawal symptoms in rats chronically treated with morphine and then administered a narcotic antagonist. Unfortunately, at the present time the clinical fate of felbamate is somewhat problematic. Specifically, although felbamate was approved by the FDA in 1994 for the treatment of intractable epilepsy in children, its clinical use was greatly curtailed by reports of deaths from aplastic anemia associated with this use. This is thought to be an isolated effect associated with this specific agent and one that is not common to all glycine site antagonists.

Thus, glycine agonists and antagonists may be considered as clinical entities for the treatment of opiate addiction in the future. However, much further preclinical research is to clarify their effects in both opioid tolerance and withdrawal.

\section{NITRIC OXIDE SYNTHASE INHIBITORS}

NMDA receptor antagonists appear to inhibit both opioid tolerance and withdrawal. Although the biological mechanism underlying these pharmacologic effects is presumed to be blockade of the NMDA receptor complex (NMDA-RC), other related molecular mechanisms may be involved. Stimulation of neuronal nitric oxide (NO) may occur during opioid tolerance and withdrawal. Activation of the NMDA-RC stimulates the enzymatic production of NO, and, therefore, NMDA receptor antagonists can indirectly reduce the activity of NOS (see Garthwaite 1991 for a review). NO appears to be a neurotransmitter and a messenger in target cells. although it is an unconventional neurotransmitter and simply diffuses out to its target site (Martin and Gillespie 1990; Bredt and Snyder 1992; Culotta and Koshland 1992). The immunocytochemical distribution of brain NOS (amygdala, central grey, spinal tract of the trigeminal nerve and the substantia gelatinosa of the spinal cord) is consistent with a role for NOS in some aspect of the $m u$ opioid analgesia/tolerance/ withdrawal process (Bredt et al. 1990, 1991; Synder and Bredt 1991).

The link between NO and NMDA receptors is derived from research suggesting that NMDA can elicit increases in cGMP levels in rat hippocampal slice preparations and that these can be blocked by NOS inhibitors (Garthwaite et al. 1988, 1989). In addition, a relationship between NOS inhibitors, glutamate, and neuronal toxicity was illustrated in a study by Dawson et al. (1991) demonstrating that NOS inhibitors can protect rat embryonic cortical cells in culture from NMDA neurotoxicity. Indeed, the relationship between NOS and the NMDA-RC and the results of the Dawson et al. (1991) study inspired several research groups to investigate the effects of NOS inhibitors on opioid tolerance and withdrawal.

\section{NITRIC OXIDE SYNTHASE INHIBITORS AND OPIOID TOLERANCE}

Direct NOS inhibitors such as $\mathrm{L}^{\mathrm{N}} \mathrm{N}^{\mathrm{G}}$-nitroarginine (L-NNA) have been reported by at least two laboratories to inhibit and even reverse morphine tolerance in mice (Kolesnikov et al. 1992, 1993b; Elliott et al. 1994b), and at least one laboratory has recently shown that $\mathrm{L}-\mathrm{N}^{\mathrm{G}}$-monomethylarginine (L-NMMA) inhibits morphine tolerance in rats (Bhargava 1995a; see Table 5).

Table 5. Effects of Nitric Oxide Synthase Inhibitors on $M u$ (Morphine) Opioid Tolerance and Withdrawal

\begin{tabular}{|c|c|c|c|c|c|c|}
\hline Drug Name & Abbreviation & $\begin{array}{l}\text { Inhibition of } \\
M u \text { Tolerance }\end{array}$ & $\begin{array}{c}\text { Inhibition of } \\
M u \text { Withdrawal }\end{array}$ & $\begin{array}{c}\text { Increase } \\
\text { BP }\end{array}$ & $\begin{array}{c}\text { Vascular } \\
\text { NOS }\end{array}$ & $\begin{array}{c}\text { Clinical } \\
\text { Potential } \\
\end{array}$ \\
\hline $\mathrm{L}-\mathrm{N}^{\mathrm{C}}$-nitroarginine & L-NNA & $\operatorname{Yes}^{a b}$ & Yes $^{a, c, d, e, f}$ & $\mathrm{No}^{a}, \mathrm{Yes}^{d}$ & Yes & Possibly \\
\hline $\begin{array}{l}\mathrm{L}-\mathrm{N}^{\mathrm{C}} \text {-monomethylarginine } \\
\mathrm{L}-\mathrm{N}^{\mathrm{C}} \text {-nitroarginine }\end{array}$ & L-NMMA & Yest & $\mathrm{Yes}^{e}+\mathrm{tg}, \mathrm{No}^{\mathrm{e}}$ & NT & Yes & Possibly \\
\hline methyl ester & L-NAME & NT & Yes ${ }^{i, d e . f}$ & $Y_{e s}^{d}$ & Yes & No \\
\hline $\mathrm{N}(5)$-(1-iminoethyl-L-ornthine) & L-NIO & $\therefore \mathrm{T}$ & Yes $^{d}$ & Yes $^{d}$ & Yes & No \\
\hline 7-nitroindazole & $7-\mathrm{NI}$ & NT & Yes ${ }^{i t}$ & $\mathrm{No}^{d}$ & No & Yes \\
\hline Methylene blue (indirect) & MB & Yes & NT & NT & No & Yes \\
\hline
\end{tabular}

$\mathrm{BP}=$ blood pressure as it occurs during withdrawal from chronically administered $m u$ opioid agonists such as morphine; vascular NOS = effects on vascular epithelial NOS; clinical potential = refers only to treatment of a specific aspect of opiate addiction.

"Kolesnikov et al. (1993b)

"Elliott et al. (1994b).

' Kimes et al. (1993).

"Vaupel et al. (1995).

"Cappendijk et al. (1993).

Thorat et al. (1994).

Bhargava (1995a).

"Babey et al. (1994) 
These groups capitalized on the action of L-NNA to inhibit irreversibly NOS (Dwyer et al. 1991) by showing the longevity of inhibition of tolerance produced by L-NNA weeks after its administration. (For further details, see Pasternak et al. this volume and Elliott this volume). In addition, a third study (Babey et al. 1994) has demonstrated that the indirect NOS inhibitor methylene blue (MB) significantly inhibits morphine tolerance in mice. Therefore as indicated in Table 5, some NOS inhibitors (L-NNA, L-NMMA, MB) should have been reported to inhibit $m u$ opioid tolerance.

One of the first investigations into the effects of L-NNA on opioid tolerance was reported by Kolesnikov et al. (1993b) using CD-1 mice (see also Kolesnikov et al. 1992). These experiments demonstrated the following four characteristics of L-NNA and morphine tolerance:

1. L-NNA inhibited the development of morphine tolerance in mice. Tolerance to morphine was produced by implanting a morphine pellet ( $75 \mathrm{mg} \mathrm{SC}$ ) in mice. Coadministration of L-NNA ( $4 \mathrm{mg} / \mathrm{kg}$ IP) for 5 days markedly inhibited the development of tolerance (e.g., $50 \%$ of mice were analgesic on day 5 ). Similar inhibitory effects of L-NNA on morphine tolerance in CD-1 mice were also obtained by Elliott et al. (1994b).

2. The effects of $L-N N A$ in inhibiting the development of morphine tolerance were long-lasting. Tolerance was induced by daily injections of morphine $(5 \mathrm{mg} / \mathrm{kg} \mathrm{SC})$. Administration of a daily dose of $2 \mathrm{mg} / \mathrm{kg}$ of L-NNA maintained the analgesic response to morphine for over 4 weeks.

3. L-NNA slowly reversed morphine tolerance after it occurret over 5 days. Inded, L-NNA reversed tolerance in a superior fashion than complete withdrawal from morphine!

4. The effects of $L-N N A$ were specific to tolerance and cannot be explained as a pharmacological additive response on analgesia plus tolerance. L-NNA ( $2 \mathrm{mg} / \mathrm{kg}$ IP) by itself failed to produce an analgesic response when administered either acutely or chronically, and it also failed significantly to influence the analgesic potency of morphine in opiate-naive mice (Elliott et al. 1994b). Therefore, these effects cannot represent a simple summation of separate analgesic effects of two agents (morphine, L-NNA).

These results document the unusual pharmacological feature of NMDA receptor antagonists and NOS inhibitors that when using these agents a separation can be achieved between morphine analgesia and tolerance.

The specificity of these effects of NOS inhibitors to $m u$ versus kappa opioid tolerance is more controversial. On the one hand, some researchers have failed to find significant effects of L-NNA on the tolerance to kappa opioid analgesic effects. Both Kolesnikov et al. (1993b) and Elliott et al. (1994b) examined the effects of L-NNA on the tolerance to the analgesic effects induced by two kappa opioid agonists: a kappa ${ }_{1}$ ligand, $U 50488 \mathrm{H}$, and a kappa 3 ligand, $\mathrm{NalBzoH}$, and results of both investigations indicated that L-NNA did not prevent the tolerance to the analgesia mediated by either of these kappa agonists. On the other hand, a different NOS inhibitor, L-NMMA, has been reported to inhibit the tolerance of the analgesic actions of $\mathrm{U} 50488 \mathrm{H}$ in both the mouse (Thorat et al. 1993) and the rat (Bhargava 1994). The nature of this difference in results is not clear but may reflect the specific mouse or rat strain employed or some subtle pharmacological difference between L-NNA versus L-NMMA.

Babey et al. (1994) have explored the intermediary biochemical steps underlying this effect of L-NNA on morphine tolerance in CD-1 mice. Rather surprisingly, these investigators failed to find a significant effect of chronic morphine administration on NOS levels in either brainstem or cerebellum and/or on levels of NOS mRNA in a variety of brain regions. These results contrast with significant upregulation of NOS obtained of NOS obtained in certain brain regions obtained by others in a preliminary report (Barjavel and Bhargava 1994). However, a role of L-arginine (a reciprocal NOS manipulation) in the NOS/opioid tolerance process was indicated in the Babey et al. (1994) study. Indeed, L-arginine was found to accelerate morphine tolerance, and this effect was blocked by L-NNA. By comparison, $\mathrm{L}$-arginine had no significant effects on the tolerance to $k_{a p p a_{1}}$ and kappa $_{3}$ opioid agonists, indicating once again a role of the NO system in $m u$, but not in kappa, opioid systems.

In addition, Babey et al. (1994) described the results of an interesting experiment that $\mathrm{MB}(1$ and $10 \mathrm{mg} / \mathrm{kg}$ $\mathrm{SC})$, an indirect NOS inhibitor, blocked the tolerance to morphine's analgesic effects in CD-1 mice. The clinical importance of this observation is that $\mathrm{MB}$ is already on the market in the United States as tablets to be administered orally in several forms. These medications containing $\mathrm{MB}$ are approved by the FDA for the relief of discomfort of the lower urinary tract caused by hypermotility resulting from inflammation associated with cystistis, urethritis, or trigonitis. Thus, the proven safety of MB makes it an excellent clinical candidate for assessing the role of NOS inhibitors in opioid tolerance and withdrawal.

\section{NITRIC OXIDE SYNTHASE INHIBITORS AND OPIOID WITHDRAWAL}

There are at least six separate reports indicating that NOS inhibitors [L-NNA, L-NMMA, L-NG-nitroargininemethylester (L-NAME), N(5)-I-iminoethyl-L-orni- 
thine (L-NIO), 7-nitroindazole (7-NI)] inhibit the development of morphine opioid withdrawal in murine species. NOS inhbitors have been shown to attenuate some of the symptoms of opioid withdrawal in rats (Kimes et al. 1991, 1993; Vaupel et al. 1995 and this volume; Bhargava 1995a) and in mice [Cappendijk 1993; (some measures) Kolesnikov et al. 1993b; Matwyshyn et al. 1993; Thorat et al. 1994] and to reverse already established opiate dependence (i.e., withdrawal symptoms) in mice (Kolesnikov et al. 1993b) (see Table 5). For further details see Vaupel et al. this volume and Pasternak et al. this volume.

Kimes et al. (1993) (preliminary report in Kimes et al. 1991) showed that L-NNA (7.5 mg/kg IP) inhibited certain naloxone-precipitated opioid withdrawal symptoms, including wet dog shakes and weight loss, in morphine-dependent rats. L-NAME was 10 -fold less potent than L-NNA in producing these effects. Dependence was induced by implanting three $75-\mathrm{mg}$ morphine pellets in rats. The NOS inhibitors were administered during these days, and withdrawal was precipitated with naloxone $(0.5 \mathrm{mg} / \mathrm{kg} \mathrm{SC})$. There were several other opioid withdrawal responses that were not significantly affected by L-NNA (i.e., naloxoneinduced hyperactivity and jumping). The relative potencies of L-NNA and L-NAME in inhibiting certain types of opioid withdrawal show a relationship to the efficacy of these drugs as NOS inhibitors (Rees et al. 1990; Lambert et al. 1991).

In a follow-up study Vaupel et al. (1995) reported on the efficacy of four NOS inhibitors to decrease naloxone-precipitated morphine withdrawal in rats (one 75-mg morphine pellet) was used to induce dependency). Results indicated that 7-NI, L-NIO, L-NAME, and L-NNA all produced significant dose-related decreases in weight loss, diarrhea, wet dog shakes, and grooming. However, other severe symptoms of withdrawal, such as "hyperactivity," were not inhibited. Opioid-dependent rats showed about three-fold increases (day 4) in exploratory activity, and this "opioid withdrawal hyperactivity" was significantly increased (worsened) by 7-NI, L-NIO, and L-NNA while L-NAME had no effect. A positive control, clonidine (an alpha2 -adrenergic agonist commonly used "off-label" for the treatment of opioid withdrawal), showed that the inhibitory effects induced by 7-NI on opioid withdrawal symptoms were comparable to those obtained with this medication. Clonidine also increased the "hyperactivity of opioid withdrawal." However, clonidine significantly. reduced blood pressure (BP), an effect not observed with 7-NI.

Effects on BP is a side effect of great clinical significance in the development of NOS inhibitors. NO produces hypotension through its activation of vascular epithelial NOS (Garthwaite et al. 1988; Bredt and Synder 1992; Xie et al. 1992). The reverse state, hyper- tension, is produced by the majority of NOS inhibitors because they inhibit the production of NOS in vascular epithelial tissue (Babbedge et al. 1993; Moore et al. 1993a, 1993b). An important finding of the Vaupel et al. (1995) study in rats was that three of the NOS inhibitors (L-NAME, L-NNA, L-NIO) induced significant increases in BP with the sole exception of 7-NI. These results suggest that 7-NI may be of particular interest in human treatment trials for certain aspects of opiate addiction (see below). In contrast with Vaupel et al. (1995), Kolesnikov et al. (1993b) failed to find a significant effect of L-NNA on mean arterial blood pressure (MAP) in mice. This may represent a species difference between rats and mice, since Kolesnikov et al. (1993b) also report a dramatic elevation in MAP with L-NNA in rats.

Support for these findings has also been obtained by Kolesnikov et al. (1993b) in CD-1 mice. Jumping was used to assess the effects of L-NNA on naloxoneprecipitated ( $1 \mathrm{mg} / \mathrm{kg} \mathrm{SC}$ ) opioid withdrawal in mice chronically administered morphine $(5 \mathrm{mg} / \mathrm{kg} \mathrm{SC})$. L-NNA induced dose-dependent decreases in naloxone-precipitated jumping. Although the overall interpretation is similar to that made by Kimes et al. (1993) that L-NNA inhibits naloxone-precipitated morphine withdrawal, it is of interest that "jumping" was not significantly influenced by L-NNA in the Kimes et al. (1993) study or in the follow-up investigation by Vaupel et al. (1995). Careful examination of data presented by Kimes et al. (1993, Table 1 of that paper) suggests that the differences in results between the two studies are probably not due to a species difference in rats versus mice but, rather, due to subtle differences in methodology or post hoc statistical analyses. Accordingly, it would be valuable to conduct a side-by-side comparison in mice versus rats for L-NNA on naloxone-precipitated morphine withdrawal jumping in the same laboratory to resolve these discrepancies across investigations.

Results similar to the effects of NOS inhibitors on narcotic antogonist-induced opioid withdrawal in mice found by Kolesnikov et al. (1993b) have been reported by other investigators (Cappendijk et al. 1993; Matwyshyn et al. 1993; Thorat et al. 1994), and each of these studies indicates that withdrawal "jumping" in mice is inhibited by L-NNA and L-NAME while the effects of L-NMMA are more controversial. Cappendijk et al. (1993) failed to find a significant effect of L-NMMA (3.5 to $100 \mathrm{mg} / \mathrm{kg}$ ) on morphine withdrawal symptoms in mice. This latter result differs from that reported by Thorat et al. (1994) who found that L-NMMA (0.02 to $4.0 \mathrm{mg} / \mathrm{kg} \mathrm{SC}$ ) reduced withdrawal jumping (but no other symptoms) in morphine-dependent (one 75-mg pellet) mice. Methodological differences (e.g., in the dose of morphine or narcotic antagonist used) may underlie some of the differences obtained for L-NMMA (Bhargava 1994). 
Results of the Kolesnikov et al. (1993b) investigation also revealed that L-NNA reversed previously established morphine dependence. Mice receiving L-NNA for 5 days with continued morphine administration showed essentially little or no naloxone-precipitated withdrawal jumping in comparison with mice receiving just morphine for this period. Therefore, NOS inhibitors may not have to be administered during the development of $m u$ opioid agonist dependence to effectively inhibit opioid withdrawal. However, none of the investigations address the question of whether NOS inhibitors can inhibit morphine withdrawal once it is expressed. Indeed, heroin addicts are typically referred for medical intervention when they are actively expressing opioid withdrawal symptoms, not when they are in a stable opioid state. Of course, this does not preclude initially stabilizine an opioid-dependent individual with an orally administered opioid agonist along with a NOS inhibitor for several days and then withdrawing the opioid agonist.

Overall, there is striking evidence across at least four different laboratories that NOS inhibitors decrease narcotic-induced abstinence in both mice (Cappendijk et al. 1993; Kolesnikov et al. 1993b; Matwyshyn et al. 1993; Thorat et al. 1994) and in rats (Kimes et al. 1993; Vaupel et al. 1995 and this volume; Bhargava 1995a). Further research is needed to determine whether there is a murine species difference in the capacity of NOS inhibitors to effect "jumping" versus other opioid withdrawal responses. Such differentiation may provide a preclinical tool for predicting the efficacy of NOS inhibitors in influencing the "hyperactivity" versus other symptoms (gastroenterological, psychological) of opi. oid withdrawal in humans.

As indicated in Table 5, there are reports on at least five NOS inhibitors and opioid withdrawal in rodents, and all indicate that these drugs inhibit opioid withdrawal in either mice or rats. Three (L-NNA, L-NMMA, $\mathrm{MB}$ ) of these agents have been investigated for their effects on opioid tolerance, and results of three studies indicate that L-NNA or MB inhibits morphine tolerance (Kolesnikov et al. 1993b; Babey et al. 1994; Elliott et al. 1994b; Bhargava 1995a). 7-NI (and probably MB) are the only NOS inhibitors tested to date that would not be expected to have hypertensive side effects, and, therefore, have clinical potential relative to other NOS inhibitors pending results of future investigations. Of all the direct NOS inhibitors, 7-NI appears to be in the lead as a clinical candidate for the treatment of opioid withdrawal because it does not appear to affect vascular epithelial NOS (Babbedge et al. 1993; Moore et al. 1993a and 1993b) and as a consequence does not have any significant effects on BP in either opioid-naive mice (Moore et al. 1993b) or in opioid-dependent rats undergoing opioid antagonist-precipitated withdrawal (Vaupel et al. 1995 and this volume). In contrast, L-NNA
L-NAME, and L-NIO all affect vascular epithelial NOS and have been shown significantly to increase BP in rodents (Babbedge et al. 1993; Moore et al. 1993a, 1993b; Vaupel et al. 1995 and this volume). MB appears to be the lead candidate for indirect NOS inhibitors for this indication (Babey et al. 1994), also because of the probable lack of effect on blood pressure.

\section{NEUROTOXICITY ISSUES ASSOCIATED WITH NMDA RECEPTOR ANTAGONISTS}

A pivotal issue concerning the therapeutic use of NMDA receptor antagonists is neurotoxicity and other serious side effects that have been associated with this class of drugs. Because of these concerns, the clinical development of NMDA receptor antagonists (and NOS inhibitors) has been slowed over the last several years and the clinical development of these agents for the treatment of stroke, head trauma, epilepsy, chronic pain, Parkinson's disease, and drug addiction remains poised for the resolution of these important issues. A review of these neurotoxicity issues was sponsored by the National Institute of Mental Health-Psychotherapeutic Medications Development Program (NIMHPMDP) in 1994, and results of this conference are reported in Psychopharmacology Bulletin. Included in these reports is a summary by the conference organizer (Haigler 1994) and a review of the salient regulatory issues underlying FDA approval of these drugs (Leber 1994). (For details of the potential neurotoxicity of NMDA receptor antagonists, see Olney et al. this volume).

It has been clearly demonstrated that noncompetitive NMDA receptor antagonists can cause acute neuronal vacuolization in a small number of neurons in the cingulate and retrosplenial cortex of rodent brain (Olney et al. 1989, 1991; Auer and Coulter 1994) and that a small proportion of these affected neurons can undergo necrosis (Fix et al. 1993). However, very recent research has questioned the clinical significance of these results. First, vacuole formation does not occur if frozen, rather than aldehyde-fixed, rodent brain is examined (Auer 1994; Auer and Coulter 1994), suggesting the possibility that the previously reported neurotoxic effects of NMDA receptor antagonists in rodent brain may reflect a "fixative artifact." Second, the vacuole formation associated with NMDA receptor antagonists appears to be reversed over time and, paradoxically, occurs only when NMDA receptor antagonists are acutely iersus chronically administered (Olney et al. 1989, 1991; Auer and Coulter 1994). In addition, vacuolization is inhibited by pretreatment with a variety of pharmacological agents (Olney et al. 1991; Olney 1994). Third, and most important, there is now evidence that this effect may be specific to rodents, because vacuolization has not been obtained in squirrel monkeys given a high 
dose of MK801 (Auer 1994). These issues and related ones are discussed in greater detail in the following.

The neurotoxic effect of glutamate in brain and the protection afforded by NMDA receptor antagonists have been clearly demonstrated. Following the discovery that iontophoretic application of glutamate excited nerve cells (Curtis and Watkins 1963), it was reported that systemic administration of glutamate produced hypothalamic lesions in the infant mouse (Olney 1969) and in infant primates (Olney et al. 1972). Further evidence for a glutamatergically mediated toxicity to neurons was inferred by demonstrating that pharmacologically active glutamate analogues produced toxicity in parallel potency to their excitatory actions whereas inactive analogues lacked toxicity (Olney 1971). Continued evaluation of structural analogues of glutamate revealed two important features: differential sensitivity to the agonists kainic acid quisqualate and NMDA (which has demonstrated utility in subtyping glutamate receptors) and the usefulness of NMDA receptor antagonists to prevent this toxicity (Watkins 1978; Watkins and Evans 1981).

The NMDA receptor antagonists a-aminoadipate and D-2-amino-5-phosphonopentanoate were shown to afford protection from the neurotoxic effect of NMDA-mediated activity in the mouse (Olney et al. 1979, 1981). Potency screening for the capacity of competitive and noncompetitive NMDA antagonists to inhibit the effects of glutamate and NMDA in in vitro preparations has been summarized (Olney 1991). Moreover, the neurotoxic effects of glutamate appear to be a consequence of (possibly excessive) NMDA receptor activation following ischemic or traumatic events (Choi 1988). The mechanism is thought to be excessive or prolonged opening of the ion channel that allows $\mathrm{Ca}^{++}$ions to accumulate and begin a cascade of neuronal processes leading to cell injury and death. Given the possible benefits to be derived from NMDA antagonists in the clinical states that may involve glutamate-induced neurotoxicity, there has been justified interest in pursuing this group of compounds for their therapeutic potential.

However, clear concerns must be addressed before the possible testing of certain NMDA antagonists in human populations can proceed. The furst issue is whether NMDA antagonists are safe to administer to human subjects, that is, whether they could be expected to induce neurotoxic effects similar to those found in rodent brain. As indicated, the regulations regarding the clinical testing of NMDA receptor antagonists may be modified based on the lack of neurotoxicity seen in nonhuman primate brain (Auer 1994). Subcutaneous administration of noncompetitive NMDA antagonists (phencyclidine, ketamine, tiletamine, and MK801) have been shown to produce a dose-related vacuolization reaction in some medium to large-size neurons of layers III and IV of the cingulate and retrosplenial cortex of adult Sprague-Dawley rats (Olney et al. 1989; Auer and Coulter 1994). Electron microscopy of affected neurons revealed that the vacuoles were formed from saccules of endoplasmic reticulum and were incorporating mitochondria and other cytoplasmic organelles. This process continued until the vacuoles had apparently digested the mitochondria. The potency of this effect was in direct relation to their potencies for the PCP binding site of the NMDA receptor complex. Other investigators (Fix 1994) have reported that dose-dependent increases in GFAP are produced in some neurons of the posterior cingulate/retrosplenial cortex of rats treated with MK801 (Fix 1994), suggesting an astroglial response to the damaged neurons.

The ability of MK801 to protect against ischemic infarct and its possible neurotoxic effects was investigated in the squirrel monkey using a middle cerebral artery occlusion paradigm (Auer 1994). Although the 1-mg/kg dose of MK801 produced behavioral effects similar to a catalepic state for $\mathbf{2 4}$ hours, it failed to reduce infarct size. (This is a very high dose of MK801, approximately equivalent to $5 \mathrm{mg} / \mathrm{kg}$ of MK801 in rats.) No lesions were noted in the cingulate or retrosplenial cortex. Although this work reflects the results of only one study, it does suggest that the NMDA receptor antagonist process of cerebral vacuolization may be murine specific and may not generalize to primates.

The second issue that must be considered in the possible development of NMDA antagonists is behavioral toxicity. PCP and ketamine have psychotomimetic properties. It is not clear whether all NMDA antagonists would share this disturbing property or whether it is limited to noncompetitive NMDA antagonists. As reviewed, behavioral studies in rodents have suggested that these PCP-like behavioral effects appear to be limited to noncompetitive rather than competitive NMDA receptor antagonists (Willetts et al. 1990; Rasmussen et al. 1991). However, there is some clinical evidence that competitive NMDA receptor antagonists also share this property. The competitive antagonists CPP (Kristensen et al. 1992), CPPene (Herrling 1994), and CGS19755 (Grotta 1994) have been reported to elicit psychotic responses in human subjects. It is not clear whether these PCP-like side effects occur only at certain high doses or whether this is a general feature of other competitive NMDA receptor antagonists. It must be remembered that the NMDA receptor complex contains multiple binding sites for a variety of ligands (e.g., glycine, polyamine). The actual site being interacted with may determine the pharmacological response elicited, and, accordingly, there is great interest in the development of glycine and polyamine NMDA receptor antagonists. 
A third issue that may influence the risk-benefit considerations in the use of NMDA receptor antagonists is the degree of receptor antagonism necessary to produce a desired response. Relative safety may be inferred if levels of receptor occupancy are sufficient to produce the desired pharmacological effect but below the level of occupancy necessary for the production of a toxic response.

Coadministration of neuroactive agents may protect against NMDA antagonist "neurotoxicity" and "behavioral psychosis" (Olney 1994). Diazepam has been reported to suppress ketamine-induced emergence reactions (Reich and Silvay 1989), suggesting that increased GABAergic transmission may modulate this behavioral toxicity. Olney et al. (1991) have reported that a variety of agents protect against NMDA receptor antagonist neurotoxicity, including diazepam, $\mathrm{m}_{1}$ muscarinic anticholinergic agents (e.g., scopolamine, atropine), and barbiturates (e.g., pentobarbital, secobarbital). Therefore, the combined administration of NMDA receptor antagonists with one of these agents (e.g., diazepam) may be another method used to eliminate possible "neurotoxic" or "PCP-like" side effects of the NMDA receptor antagonists.

Interestingly, and an important point in the opiate addiction field, the effects of opioid agonists on this NMDA receptor antagonist neurotoxic effect remains to be investigated (Olney et al. this volume). However, given that MK801 potentiates morphine lethality in rats (Trujillo and Akil 1991b), the combination of this type of noncompetitive NMDA antagonist and an opiate may be too dangerous for human use. On the other hand. given its widespread availability as a nonprescription medication, it is likely that DM (also a noncompetitive NMDA receptor antagonist) does not produce similar neurotoxic effects. Therefore, studies are needed to determine whether DM induces vacuole formation in animal brain (in both the opiate-naive and opiatedependent animal) and if the combination of DM and morphine in humans differentially affects the analgesic versus respiratory tolerance associated with chronically administered $m u$ opiate agonists.

\section{CONCLUSIONS: CLINICAL SIGNIFICANCE}

The clinical signifiance of these results for the treatment of opiate addiction lies in the introduction of the NMDA receptor antagonists and NOS inhibitors for at least three indications related to opiate addiction.

First, of great interest would be to determine the efficacy of the NMDA receptor antagonists and the NOS inhibitors in the prevention of relapse to intravenously administered opiates in individuals previously medically withdrawn from opiates. Such studies would provide powerful tests of the hypothesis that the NMDA or NO system may be critically related to relapse. As indicated above, relapse is the major factor perpetuating opiate addiction (see Ball and Ross 1991). Evidence to support studies for this indication includes data in rodents implicating the NMDA receptor system in longterm potentiation (LTP) (Collingridge et al. 1983; Harris and Cotman 1986; Morris et al. 1986; Errington et al. 1987; Xie and Lewis 1991), a process that may relate to the intractability and high relapse rate associated with opiate addiction. Indeed, the interest in NMDA receptors has been stimulated by the linkage to LTP, a phenomenon that produces stable increases in synaptic efficacy and may be a neurobiological substrate involved in learning and memory (Collingridge et al. 1983; Harris and Cotman 1986; Morris et al. 1986; Errington et al. 1987). For example, Xie and Lewis (1991) have examined the effects of opioid agonists, opioid antagonists, and NMDA receptor antagonists on electrophysiological events on hippocampal slices and in the lateral performant path (LPP) of rat brain after LTP has been induced. These researchers found that a $m u$ agonist (P1017) reduced the threshold for LTP and increased the amount of LTP in the LPP and that these effects were blocked by either an opioid receptor antagonist (naloxone) or a NMDA receptor antagonist (AP5). These data suggested that exogenous opioids enhanced the efficiency of LTP, and that LTP in this pathway can be blocked by either an opioid or NMDA receptor antagonist. It is intriguing to speculate that LTP may underlie the prolonged changes in opiate responsitivity produced by chronically administered opioids and underlie relapse and that this process may be disrupted by the administration of NMDA receptor antagonists. The possible production of LTP by opioids, its interaction with the NMDA-RC, and the relationship to opioid tolerance, dependence, relapse, and drugseeking behavior warrants further investigation.

However, apart from testing LTP, it will be difficult to perform tests of this hypothesis in animals because of the paucity of agreed-upon preclinical models for assessing the efficacy of medications for inhibiting relapse to opiates. Information on the effects of these agents on preclinical models that appear to address some aspects of relapse (e.g., conditioned place preference) would be of interest, although it is notable that Trujillo and Akil (1994) provided evidence that some of these agents (noncompetitive NMDA receptor antagonists) appear to affect nonassociative rather than associative type of tolerance. In short, the findings of Trujillo and Akil (1994) suggest that the effects of the noncompetitive NMDA receptor antagonists on conditioned cues may not be critical in explaining their effects on certain aspects of opiate addiction (at least in rodents). Finally, as detailed, data on the efficacy of this class of medications to inhibit and/or to reverse the development of 
tolerance may also provide preclinical models of medications to be used in relapse prevention.

The second indication is to utilize these medications in the treatment of opioid withdrawal symptoms. Evidence to support this indication includes the significant effects of noncompetitive NMDA receptor antagonists with clinical potential (e.g., DM), competitive NMDA receptor antagonists (e.g., LY274614), glycine antagonists (e.g., felbamate, although see the problems with this medication delineated above) and direct NOS inhibitors (e.g., L-NNA, L-NMMA, 7-NI) in the treatment of morphine withdrawal in rodents (e.g., Koyuncuoglu et al. 1990; Rasmussen et al. 1991; Kimes et al. 1993; Kolesnikov et al. 1993b; Kosten et al. this volume; Vaupel et al. 1995 and this volume; MB remains to be tested for this effect; although see lack of effect reported for LY235959 by Matwyshun and Bhargava 1995). As a first step, it would seem reasonable to attempt to replicate some of the DM, LY274614, felbamate, 7-NI studies in opioid-dependent monkeys described before, since there is high predictive validity for the efficacy for most other classes of medications for the treatment of opioid withdrawal symptoms in rhesus monkeys for humans (Aceto et al. 1982, 1986, 1990).

In the case of 7-NI it may be reasonable to undertake a small inpatient trial to test this hypothesis using the injectable form of 7-NI as a frst step to assess its efficacy for the treatment of opioid withdrawal in humans. However, it is doubtful whether 7-NI will prove more effective and with lower side effects than conventional treatments (e.g., medically supervised withdrawal with methadone or alpha-2-adrenergic agonists). Indeed, it appears likely that 7-NI may exacerbate certain opioid withdrawal symptoms, including the "hyperactivity" of opioid withdrawal (e.g., Kimes et al. 1993; Vaupel et al. 1995 and this volume). Second, an advantgage of 7-NI for this indication would be suggested if 7-NI was found to affect the "psychological distress" associated with opioid withdrawal and or if 7-NI was found to influence the more prolonged symptoms of opioid withdrawal that do not appear to be affected by some other medications. Neither of these effects have been demonstrated for 7-NI, although a lack of effect of 7-NI versus clonidine on BP in humans would represent a strong third advantage (Vaupel et al. 1995;

Third, coadministering these medications with approved opiate agonist maintenance medications (e.g., methadone, LAAM) could be used to decrease the tolerance or dependence to $m u$ opiates and eventually to help an individual achieve the transition from an opiate agonist to an opiate antagonist type of therapy. Medications with this type of potential include the noncompetitive NMDA receptor antagonists (e.g., DM), the competitive NMDA receptor antagonists (e.g., LY274614), the glycine antagonists (e.g., ACPC), and the NOS inhibitors (e.g., 7-NI, L-NNA, L-NMMA, MB)
The high probability of this type of clinical intervention's working is based on the significant effects of DM (e.g., Elliott et al. 1994a), LY274614 (Tiseo and Inturrisi 1993; also see recent preliminary report of significant effects with LY235959 by Matwyshyn and Bhargava 1995), ACPC (Kolesnikov et al. 1994), L-NNA (Kolesnikov et al. 1993), L-NMMA (Bhargava 1995b), and MB (Babey et al. 1994) in inhibiting $m u$ (morphine) opioid tolerance in the rodent. The safety profile and clincial availability of $\mathrm{DM}$ and $\mathrm{MB}$ over these other medications may provide an advantage of these agents for this novel indication.

The importance of testing other NOS inhibitors such as 7-NI given its lack of side effects on BP (Vaupel et al. 1995 and this volume) in the inhibition and reversal of $m u$ opioid tolerance in rodents is clearly indicated. If these 7-NI preclinical trials are successful, then similar tests with nonhuman primates would be of interest. Subsequently, trials of 7-NI in humans would be indicated providing that the safety, toxicology, and pharmacokinetics profile of this agent proves to be satisfactory considering that $7-\mathrm{NI}$ is not yet approved by the FDA for any indication. A drawback in the clinical development of $7-\mathrm{NI}$ is that it is currently only available as an injection, and that the availability of an oral or nasal route is critical for fostering a medication for the treatment of any aspect of opiate addiction.

The future indicates that the clinical medication development of the various types of noncompetitive and competitive NMDA receptor antagonists, the glycine antagonists, and the NOS inhibitors may proceed on a faster track for the treatment of various aspects of opiate addiction than for any other indication, including stroke, head trauma, epilepsy, or Parkinson's disease. The reason for this is the substantial preclinical literature already suggesting a role for these medications in the treatment of opiate addiction and that continued self-administration of intravenous opiates is associated with considerable morbidity and mortality (e.g., AIDS). Therefore, it is of great relevance to medicine and to society in general to support pharmacological research in this important area in the future.

\section{ACKNOWLEDGMENTS}

The authors gratefully express their appreciation to Drs. E. Weber and H. Haigler and to Drs. K. Elliott, H. Heinemann, C. Inturrisi, A. Kimes, T. Kosten, E. London, D. Mayer, J. Olney, G. Pasternak, C. Rasmussen, R. Rosen, R. Rosse, $K$. Trujillo, and B. Vaupel for providing thoughtful discussion and intellectual guidance prior and during the NIDA Technical Review that led to this manuscript. Our appreciation to M. G. Palfreyman for sharing his published schematic of the NMDA receptor complex. Expert assistance in medical library research was provided by Joanne Gampel, M.A., of MDD, NIDA, assisted by LaQuanda Brown. Word processing as- 
sistance for some sections of the manuscript was provided by Anne Marie Gunderman of MDD, NIDA. This article is dedicated in the memory of Roland Ciaranello, M.D.

\section{REFERENCES}

Aceto, MD, Dewey WL, Chang JK, Lee NM (1982): Dynorphin (1-13) effects in nontolerant and morphine-dependent rhesus monkeys. Eur J Pharmacol 83:139-142

Aceto MD, Dewey WL, Portoghese PS, Takemori AE (1986) Effect of $\beta$-funaltrexamine ( $\beta$-FNA) on morphine dependence in rats and monkeys. Eur J Pharmacol 123:387-393

Aceto MD, Bowman ER, Harris LS (1990): Dependence studies of new compounds in the rhesus monkey, rat and mouse NIDA Res Monogr 95:578-631

Aghajanian GK (1978): Tolerance of locus coeruleus neurons to morphine and suppression of withdrawal responses by clonidine. Nature 276:186-188

Akaoka H, Aston-Jones G (1991): Opiate-withdrawal-induced hyperactivity of locus coeruleus neurons is substantially mediated by augmented excitatory amino acid input. I Neurosci 11:3830-3839

Albers GW, Saenz RE, Moses JA, Choi DW (1991): Safety and tolerance of oral dextromethorphan in patients at risk for brain ischemia. Stroke 22:1075-1077

Auer RN (1994): Assessing structural changes in the brain to evaluate neurotoxicological effects of NMDA receptor antagonists. Psychopharmacol Bull 30:585-592

Auer RN, Coulter KC (1994): The nature and time course of neuronal vacuolation induced by the NMDA antagonist MK-801. Acta Neuropathol (Berl) 87:1-7

Babbedge RC, Bland-Ward PA, Hart SL, Moore PK (1993): Inhibition of rat cerebellar nitgric oxide synthase by 7 -nitro indazole and related substituted indazoles. $\mathrm{Br} J \mathrm{Ph}$ armacol 110:225-228

Babey A-M, Kolesnikov Y, Cheng J, Inturrisi CE, Trifilletti RR, Pasternak GW (1994): Nitric oxide and opioid toler ance. Neuropharmacology 33:1463-1470

Ball JC, Ross A (1991): The Effectiveness of Methadone Main tenance Treatment. New York, Springer-Verlag

Barjavel MJ, Bhargava HN (1994): Effect of morphine tolerance and abstinence on nitric oxide synthase activity in brain regions and spinal cord of the mouse. Soc Neurosci 20:1234

Baron BM, Kehne JH, Sorensen SM, Harrison BL, Salituro FG, White $S$ (1994): Design and pharmacological evaluation of highly selective glycine antagonists. In Palfreyman MG, Reynolds, IJ, Skolnick P (eds), Direct and Allosteric Control of Glutamate Receptors. Boca Raton, FL. CRC Press, pp 105-117

Ben-Eliyahu S, Marek P, Vaccarino AL, Mogil JS, Sternberg WF, Liebskind JC (1992): The NMDA receptor antagonist MK-801 prevents long-lasting non-associative morphine tolerance in the rat. Brain Res 575:304-308

Bhargava HN (1978): The effects of naltrexone on the development of physical dependence on morphine. Eur J Pharmacol 50:193-202

Bhargava HN (1994): Diversity of agents that modify opioid tolerance, physical dependence, abstinence syndrome, and self-administration behaviors. Pharmacol Rev 46: 293-324

Bhargava HN (1995a) Attenuation of tolerance to, and physical dependence on, morphine in the rat by inhibition of nitric oxide synthase. Gen Pharmacol 26:1049-1053

Bhargava HN (1995b) Non-competitive antagonism of NMDA receptor inhibits tolerance to $U 50,499 \mathrm{H}$, a kappa opioid receptor agonist in the rat. Gen Pharmacol 26:1055-1060

Bhargava HN, Matwyshyn GA (1993): Dizocilpine (MK-801) blocks the tolerance to the analgesic but not to the hyperthermic effect of morphine in the rat. Pharmacology 47:344-350

Bhargava HN, Thorat SN (1994): Effect of dizocilpine (MK$801)$ on analgesia and tolerance induced by $U-50,488 \mathrm{H}$, a kappa-opioid receptor agonist in the mouse. Brain Res 649:111-116

Bhargava HN, Matwyshyn GA, Gerk PM, Bozek PS, Bailey MD, Ko KH, Simko RJ, Thorat SN (1994): Effect of naltrexone pellet implantation on morphine tolerance and physical dependence in the rat. Gen Pharmacol 25:149-155

Bhargava HN, Reddy PL, Gudehithlu KP (1995a): Downregulation of $\mathrm{N}$-methyl-D-aspartate (NMDA) receptors of brain regions and spinal cord of rats treated chronically with morphine. Gen Pharmacol 26:131-136

Bhargava HN, Matwyshyn GA, Gudehithlu KP (1995b): Effect of acute and chronic administration of dizocilpine (MK801 ) on the analgesic action of $U-50,488 \mathrm{H}$ and brain and spinal cord kappa-opioid receptors. FASEB J Abstr 9:A102

Boje KM (1994): In vitro and in vivo studies with glycine partial agonists: A novel strategy for preventing NMDA receptor-mediated tissue damage. In Palfreyman MG, Reynolds IJ, Skolnick P (eds), Direct and Allosteric Control of Glutamate Receptors. Boca Raton, FL, CRC Press, pp 119-126

Bonuccelli U, Del Dotto P, Piccini P, Behge F, Corsini GU, Muratorio A (1992): Dextromethrophan and parkinsonism [letter]. Lancet 340:53

Boulter J, Hollmann M, O'Shea-Greenfield A, Hartley M, Deneris E, Maron C, Heinemann S (1990): Molecular cloning and functional expression of glutamate receptor subunit genes. Science 249:1033-1037

Bredt DS, Snyder SH (1992): Nitric oxide, a novel neuronal messenger. Neuron 8:3-11

Bredt DS, Huang PM, Snyder SH (1990): Localization of nitric oxide synthase indicating a neural role for nitric oxide. Nature 347:768-770

Bredt DS, Glatt CE, Huang PM, Fotuhi M, Dawson TM, Snyder SH (1991): Nitric oxide synthase protein and mRNA discretely localized in neuronal populations of the mammalian CNS together with NADPH diaphorase. Neuron 7:615-624

Brent PJ, Chahl LA (1993): Enhancement of the opiate withdrawal response by antipsychotic drugs in guinea-pigs is not mediated by sigma binding sites. Eur J Neuropsychopharmacol 3:23-32

(appendijk SLT, Devries R, Dzolijc MR (1993): Inhibitory effect of nitric oxide (NO) synthase inhibitors on naloxone-precipitated withdrawal syndrome in morphinedependent mice. Neurosci Lett 162:97-100

Choi DW (1988): Glutamate neurotoxicity and diseases of the nervous system. Neuron 1:623-634 
Collingridge GL, Kehl SJ, McLennan H (1983): Excitatory amino acids in synaptic transmission in the schaffer collateral-commissural pathway of the rat hippocampus. J Physiol 334:33-46

Culotta E, Koshland DE Jr (1992): Molecule of the year. NO news is good news. Science 258:1862-1865

Curtis DR, Watkins JC (1963): Acidic amino acids with strong excitatory actions on mammalian neurons. J Physiol $166: 1-14$

Dawson VL, Dawson TM, London ED, Bredt DS, Synder SH (1991): Nitric oxide mediates glutamate neurotoxicity in primary cortical cultures. Proc Natl Acad Sci U S A 88:6368-6371

Dourish CT, Hawley D, Iversen SD (1988): Enhancement of morphine analgesia and prevention of morphine tolerance in the rat by the cholecystokinin antagonist, L-364,718. Eur J Pharmacol 147:469-472

Dourish CT, O'Neill MF, Coughlan J, Kitchener SJ, Hawley D, Iversen SD (1990): The selective CCK-B antagonist L-365,260 enhances morphine analgesia and prevents morphine tolerance in the rat. Eur J Pharmacol 176:35 44

Dwyer MA, Bredt DS, Snyder SH (1991): Nitric oxide synthase: Irreversible inhibition by $\mathrm{L}-\mathrm{N}^{\mathrm{G}}$-nitroarginine in brain in vitro and in vivo. Biochem Res Commun 176 $1136-1141$

Elliott K, Kest B, Inturrisi CE (1995): NMDA receptors, mu and kappa opioid tolerance, and perspectives on new drug development in pain. Neuropsychopharmacology 13: 347-356

Elliott K, Hyansky A, Inturrisi CE (1994a): Dextromethorphan attenuates and reverses analgesic tolerance to morphine. Pain 59:361-368

Elliott K, Minami N, Kolesnikov YA, Pasternak GW, Inturrisi CE (1994b): The NMDA receptor antagonists, LY274614 and MK-801, and the nitric oxide synthase in hibitor, $\mathrm{N}^{\mathrm{G}}$-nitro-L-arginine, attenuate analgesic tolerance to the mu-opioid morphine but not to kappa opioids. Pain 56:69-75

Errington ML, Lynch MA, Bliss TV (1987): Long-term potentiation in the dentate gyrus: Induction and increased glutamate release are blocked by $\mathrm{D}(-)$ aminophosphonovalerate. Neurosci 20:279-284

Fisher RS, Cysyk BJ, Lesser RP, Pontecorvo MJ, Ferkany | I. Swederdt PR, Hart J, Gordon B (1990): Dextromethorphan for treatment of complex partial seizures. Neurology 40:547-549

Fix AS (1994): Pathological effects of MK-801 in the rat posterior cingulate/retrosplenial cortex. Psvchophar macol Bull 30:577-584

Fix AS, Horn JW, Wightman KA, Johnson CA, Long (i i, Storts RW, Farber N, Wozniak DF, Olney JW (1993): Neuronal vacuolization and necrosis induced by the noncompetitive $\mathrm{N}$-methyl-D-aspartate (NMDA) antagonist $\mathrm{MK}(+) 801$ (dizocilpine maleate): A light and electron microscopic evaluation of the rat retrosplenial cortex. Exp Neurol 123:204-215

Foster AC, Kemp JA (1988): HA-966 antagonizes N-methyl$\mathrm{D}$-aspartate receptors through a selective interaction with the glycine modulatory site. J Neurosci 9:2191-2196

Garthwaite J (1991): Glutamate, nitric oxide and cell-cell signalling in the nervous system. TINS 14:60-67

Garthwaite J, Charles SL, Chess-Williams R (1988): Endothelium-derived relaxing factor release on activation if
NMDA receptors suggests role as intercellular messenger in the brain. Nature $336: 385-388$

Garthwaite J, Southam E, Anderton M (1989): A kainate receptor linked to nitric oxide synthesis from arginine. J Neurochem 53:1952-1954

Grönbladh L, Ohlund LS, Gunne LM (1990): Mortality in heroin addiction: Impact of methadone treatment. Acta Psychiatr Scand 82:223-227

Grotta J (1994): Safety and tolerance of the glutamate antagonist CGS 19755 in acute stroke patients. Stroke 25:255

Gudehithlu KP, Reddy PL, Bhargava HN (1993): Effect of chronic morphine treatment on the binding of ${ }^{3} \mathrm{H}$ MK801 to rat brain and spinal cord membranes. Pharmacologist 35:A190

Gudehithlu KP, Reddy PL, Bhargava HN (1994): Effect of morphine tolerance and abstinence on the binding of $3 \mathrm{H}$ MK 801 to rat brain regions and spinal cord of the rat. Brain Res 639:269-274

Gutstein HB, Trujillo KA (1993): MK-801 inhibits the development of morphine tolerance at spinal sites. Brain Res 626:332-334

Haigler HJ (1994): NMDA receptor antagonists: Neurotoxicity evaluation. Psychopharmacol Bull 30:525

Harris EW, Cotman CW (1986): Long-term potentiation of guinea pig mossy fiber responses is not blocked by N-methyl-D-aspartate antagonists. Neurosci Lett 70: 132-137

Herman BH, Vocci F, Majewska D, Bridge P (1993): Development of glutamatergic antagonists: New treatments for opiate addiction. NIDA Research Monograph 141, Vol II, Problems of Drug Dependence: Proceeding of the 55th Annual Scientific Meeting, College on Problems of Drug Dependence, Inc., Toronto, Canada, June 16, p 472

Herrling PL (1994): D-CPPene (SDZ EAA 494), A competitive NMDA antagonist: Results from animal models and first results in humans. Neuropsychopharmacology 10(3):591

Hollmann M, Heinemann S (1994): Cloned glutamate receptors. Ann Rev Neurosci 17:31-108

Hollmann M, O'Shea-Greenfield A, Rogers SW, Heinemann $S$ (1989): Cloning by functional expression of a member of the glutamate receptor family. Nature 342:643-648

Hood WF, Compton RP, Monahan JB (1989): A ligand for the $\mathrm{N}$-methyl-d-aspartate coupled glycine receptor has partial agonist characteristics. Neurosci Lett 98:91-95

Hood WF, Compton RP, Monahan JB (1990): N-methyl-Daspartate recognition site ligands modulate activity at the coupled glycine recognition site. J Neurochem 54:10401046

Hood WF, Gray NM, Dappen MS, Watson GB, Compton RP, Cordi AA, Lanthorn TH, Monahan JB (1992): Characterization of indole-2-carboxylate derivatives as antagonists of N-methyl-D-aspartate receptor activity at the associated glycine recognition site. J Pharmacol Exp Ther 262:654-660

Huettner JE (1989): Indole-2-carboxylic acid: A competitive antagonist of potentiation by glycine at the NMDA receptor. Science 243:1611-1613

Jaffe DB, Marks SS, Greenberg DA (1989): Antagonist drug selectivity for isoligand binding sites on voltage-gated and N-methyl-D-aspartate receptor-gated $\mathrm{Ca}^{2+}$ channels. Neurosci Lett 105:227-232. 
Jaffe JH (1994): Drug addition and drug abuse. In Goodman Gilman A, Rall TW, Nies AS, Taylor P (eds), The Pharmacological Basis of Therapeutics, ed 8, New York, McGraw-Hill, pp 522-573

Jaffe JH, Martin WR (1994): Opioid analgesics and antagonists. In Goodman Gilman A, Rall TW, Nies AS, Taylor $P$ (eds), The Pharmacological Basis of Therapeutics, ed 8, New York, McGraw-Hill, pp 485-521

Johnson JW, Ascher P (1987): Glycine potentiates the NMDA response in cultured mouse brain neurons. Nature 325:529-531

Johnson RE, Jaffe JH, Fudala PJ (1992): A controlled trial of buprenorphine treatment for opioid dependence. JAMA 267:2750-2755

Kimes A, Vaupel DB, Bruckner M, London E (1991): Nitroarginine, a nitric oxide synthase inhibitor, attenuates morphine withdrawal. Soc Neurosci Abst 17:538

Kimes AS, Vaupel DB, London ED (1993): Attenuation of some signs of opioid withdrawal by inhibitors of nitric oxide synthase. Psychopharmacology 112:521-524

Koek W, Colpaert FC (1990): Selective blockade of N-methylD-aspartate (NMDA)-induced convulsions by NMDA antagonists and putative glycine antagonists: Relationship with phencyclidine-like behavioral effects. J Pharmacol Exp Ther 252:349-357

Kolesnikov YA, Pick CG, Pasternak GW (1992): $\mathrm{N}^{\mathrm{C}}$-nitro-Largine prevents morphine tolerance. Eur J Pharmacol 221 $399-400$

Kolesnikov YA, Ferkany ], Pasternak GW (1993a): Blockade of $m u$ and kappa, opioid analgesic tolerance by NPC17742, a novel NMDA antagonist. Life Sci 53 1489-1494

Kolesnikov YA, Pick CG, Ciszew'ska G, Pasternak GW (1993b): Blockade of tolerance to morphine but not to kappa opioids by a nitric oxide synthase inhibitor. Proc Natl Acad Sci U S A 90:5162-5166

Kolesnikov YA, Maccechini M-L, Pasternak GW (1994) I-Aminocyclopropate carbolyxic acid (ACPC) prevents mu and delta opioid tolerance. Life Sci 55:1393-1398

Kosten TR, DeCaprio JL, Rosen MI (1995): The severity of naloxone precipitated opiate withdrawal is attenuated by felbamate, a possible glycine antagonist. Neuropsy chopharmacology 13:323-333

Koyuncuoglu M, Gungor M, Sagduyu H, Aricioglu F (1990) Suppression by ketamine and dextromethorphan of precipitated abstinence syndrome in rats. Pharmacol Biochem Behav 35:829-832

Koyuncuoglu M, Saydam B (1990): The treatment of heroin addicts with dextromethorphan: A double-blind comparison of dextromethorphan with chlorpromazine. Int J Clin Pharmacol Therapy Toxicol 28:147-152

Kristensen JD, Svensson B, Gordh T Jr (1992): The NMDAreceptor antagonist CPP abolishes neurogenic "wind-up pain" after intrathecal administration in humans. Pain 51:249-253

Lambert LE, Whitten JP, Baron BM, Cheng HC, Doherty NS, MacDonald IA (1991): Nitric oxide synthesis in the CNS endothelium and macrophages differs in its sensitivity to inhibition by arginine analogues. Life Sci 48:69-75

Leber P (1994): Introduction, Psychotherapeutic Medications Development Program w'orkshop on NMDA receptor an tagonists: Neurotoxicity evaluation. Psvchopharmacol Bull 30:527-532
Ling W, Charuvastra VC, Kaim SC, Kleet CJ (1976): Methadyl acetate and methadone as maintenance treatments for heroin addicts. Arch Gen Psychiatr 33:709-720

Lufty K, Hurlbut DE, Weber E (1993): Blockade of morphineinduced analgesia and tolerance in mice. Brain Res 616:83-88

Lufty K, Shen K-Z, Kwon I-S, Cai SX, Woodward RM, Keana JFW, Weber E (1995): Blockade of morphine tolerance by ACEA-1328, a novel NMDA receptor/glycine site antagonist. Eur J Pharmacol 273:187-189

Mao J, Price DD, Mayer DJ, Lu J, Hayes RL (1992): Intrathecal MK-801 and local nerve anesthesia synergistically reduce nociceptive behaviors in rats with experimental peripheral mononeuropathy. Brain Res 576:254-262

Mao J, Price DD, Mayer DJ (1994): Thermal hyperalgesia in association with the development of morphine tolerance in rats: Roles of excitatory amino acid receptors and protein kinase C. J Neurosci 14:2301-2312

Marek P, Ben-Eliyahu S, Vaccarino AL, Liebskind JC (1991a): Delayed application of MK-801 attenuates morphine tolerance in the rat. Brain Res 558:163-165

Marek P, Ben-Eliyahu S, Gold M, Liebskind JC (1991b): Excitatory amino acid antagonists (kynurenic acid and MK801) attenuate the development of morphine tolerance in the rat. Brain Res 547:77-81

Martin W, Gillespie JS (1990): L-arginine-derived nitric oxide: The basis of inhibitory transmission in the anococcygeous and retractor penis muscles. In Bell C (ed), Novel Peripheral Neurotransmitters, New York, Pergamon Press, pp 65-79

Marquis KL, Piesla MJ, Muth EA, Boast CA (1991): Effects of acute/chronic MK-801 on naloxone-precipitated jumping in morphine-dependent mice. Soc Neurosci Abst 17:331

Marvizón J-CG, Lewin AH, Skolnick P (1989): I-Aminocyclopropane carboxylic acid: A potent and selective ligand for the glycine modulatory site of the N-methylD-aspartate receptor complex. J Neurochem 52:992-994

Matwyshyn GA, Bhargava HN (1995): Effect of LY235959, a competitive antagonist of NMDA receptor, on tolerance to and physical dependence on morphine in mice. FASEB I Abstr 9:A102

Matswyshun GA, Thorat SN, Barjavel M, Gudehithlu KP, Bhargava HN (1993): Comparative effects of MK-801 and $\mathrm{N}^{\mathrm{C}}$-monomethyl-L-arginine (NMMA) on morphine abstinence syndrome. Soc Neurosci Abstr 19:1461

Mayer DJ (1995): The role of protein kinase C in opiate tolerance, dependence and neuropathic pain. Paper presented at the NIDA Technical Review: The role of glutamatergic systems in the development of opiate addiction, October 17-18, 1995, Gaithersburg, MD

Meldrum BS (1994): Neuroprotection by NMDA and nonNMDA glutamate antagonists. In Palfreyman MG, Reynolds IJ, Skolnick P (eds), Direct and allosteric control of glutamate receptors. Boca Raton, FL, CRC Press, $127-138$

Moore, PK, Babbedge RC, Wallace P, Gaffen ZA, Hart SL (1993b): Characterization of the novel nitric oxide synthase inhibitor 7-nitro indazole and related indazoles: Antinociceptive and cardiovascular effects. $\mathrm{Br} \mathrm{J}$ Pharmacol 110:219-224

Mere PK, Babbedge RC, Wallace P, Gaffen ZA, Hart SL 1993): 7-Nitro indazole, an inhibitor of nitric oxide syn- 
thase, exhibits anti-nonciceptive activity in the mouse without increasing blood pressure. $\mathrm{Br} \mathrm{J}$ Pharmacol 108:296-297

Moriyoshi K, Masu M, Ishii T, Shigemoto R, Mizuno N Nakanishi S (1991): Molecular cloning and characterization of the rat NMDA receptor. Nature 354:31-37

Morris RG, Anderson E, Lynch GS, Baudry M (1986): Selective impariment of learning and blockade of long-term potentiation by an N-methyl-D-aspartate receptor an. tagonist, AP5. Nature 319:774-776

Mushlin BE, Cochin J (1976): Tolerance to morphine in the rat: Its prevention by naloxone. Life Sci 18:797-802

Netzer R, Pflimlin P, Trube G (1993): Dextromethorphan blocks N-methyl-D-aspartate-induced currents and voltageoperated inward currents in cultured cortical neurons. Eur J Pharmacol 238:209-216

Olney JW (1969): Brain lesions, obesity and other disturbances in mice treated with monosodium glutamate. Science $164: 719-721$

Olney JW (1971): Glutamate-induced neuronal necrosis in the infant mouse hypothalamus: An electron microscopic study. J Neuropathol Exp Neurol 30:75-90

Olney JW (1991) Excitotoxicity and neuropsychiatric disorders. In Ascher P, Choi DW, Christen Y (eds.), Glutamate, (ell Death and Memory, Heidelberg, Springer-Verlag, pp 77-101

Olney JW (1994): The neurotoxicity of NMDA receptor antagonists: An overview. Psychopharmacol Bull 30:533540

Olney JW, Faber N (1995): NMDA antagonists as neurotherapeutic drugs, psychotogens, neurotoxins and research tools for studying schizophrenia. Neuropsychopharma cology 13:335-345

Olney JW, Sharpe LG, Geigin RD (1972): Glutamate-induced brain damage in infant primates. J Neuropathol Exp Neurol 31:464-488

Olney JW, deGubareff T, Labruyere J (1979): a-Aminoadipate blocks the neurotoxic action of $\mathrm{N}$-methylaspartate. I ife Sci $25: 537-540$

Olney JW, Farber N (1995): NMDA antagonists as neurothera peutic drugs, psychotogens, neurotoxins and research tools for studying schizophrenia. Neuropsychopharmacology 13:335-345

Olney JW, Labruyere J, Collins JF, Curry K (1981): Daminophosphonovalerate is 100 -fold more powerful than D-alpha-aminoadipate in blocking $\mathrm{N}$-methylaspartate neurotoxicity. Brain Res 221:207-210

Olney IW, Labruyere J, Price MT (1989): Pathological changes induced in cerebrocortical neurons by phencyclidine and related drugs. Science 244: 1360-1362

Olney JW, Labruyere J, Wang G. Wozniak DF, Price MT Sesma MA (1991): NMDA antagonist neurotoxicity Mechanism and prevention. Science 254:1515-1518

O'Neill MF, Dourish CT, Iversen SD (1989): Morphineinduced analgesia in the rat paw pressure test is blocked by CCK and enhanced by the CCK antagonist MK-329 Neuropharmacology 28:243-247

Ornstein PL, Arnold MB, Augenstein NK, Schoepp DD, Leander JD, Lodge D (1990): The discovery of LY274614 and LY233536 and their characterization as selective and competitive NMDA antagonists. Soc Neurosci Abstr $16: 858$
Palfreyman MG (1994): Glutamate receptors and their regulators - an overview. In Palfreyman MG, Reynolds IJ, Skolnick P (eds), Direct and Allosteric Control of Glutamate Receptors, Boca Raton, FL, CRC Press, pp 1-19

Pasternak GW, Kolesnikov YA, Babey AM (1995): Perspectives on the NMDA/NO cascade and opioid tolerance. Neuropsychopharmacology 13:309-313

Psychotherapeutic medications development program (PMDP) workshop on NMDA receptor antagonists: Neurotoxicity evaluation. Psychopharmacol Bull 30:523-621

Pulvirenti L, Swerdlow NR, Koob GF (1991): Nucleus accumbens NMDA antagonist decreases locomotor activity produced by cocaine, heroin or accumbens dopamine, but not caffeine. Pharmacol Biochem Behav 40:841-845

Pulvirenti L, Maldonado-Lopez R, Koob GF (1992) NMDA receptors in the nucleus accumbens modulate intravenous cocaine but not heroin self-administration in the rat. Brain Res 594:327-330

Rasmussen K (1995): The role of the locus coeruleus and NMDA and AMPA receptors in opiate withdrawal. Neuropsychopharmacology 13:295-300

Rasmussen K, Aghajanian GK (1989): Withdrawal-induced activation of locus coeruleus neurons in opiate-dependent rats: Attenuation by lesion of the nucleus paragigantocellularis. Brain Res 505:346-350

Rasmussen K, Beitner-Johnson DB, Krstal JH, Aghajanian GK, Nestler EJ (1990): Opiate withdrawal and rat locus coeruleus: Behavioral, electrophysiological, and biochemical correlates. J Neurosci 10:2308-2317

Rasmussen K, Fuller RW, Stockton ME, Perry KW, Swinford RM, Ornstein PL (1991): NMDA receptor antagonists suppress behaviors but not norepinephrine turnover or locus coeruleus unit activity induced by opiate withdrawal. Eur J Pharmacol 197:9-16

Rees DD, Palmer RM, Schulz R, Hodson HF, Moncada S (1990): Characterization of three inhibitors of endothelial nitric oxide synthase in vitro and in vivo. $\mathrm{Br} \mathrm{J}$ Pharmacol 101:746-752

Reich DL, Silvay G (1989): Ketamine: An update on the first twenty years of clinical experience. Can J Anaesth 36:186-197

Rice DP, Kelman S, Miller LS (1991): Economic costs of drug abuse, NIDA Research Monograph 113: Economic Costs, Cost-Effectiveness, Financing, and Community-Based Drug Treatment, pp NIDA, 10-32

Rosen MI, McMahon TH, Woods S, Pearsall HR, Kosten TR (1995): The effect of dextromethorphan on naloxoneprecipitated opiate withdrawal. Paper presented at the NIDA Technical Review: The role of glutamatergic systems in the development of opiate addiction, October 17-18, Gaithersburg, MD

Saenz R, Tanner CM, Albers G, Kurth M, Tetrud J (1993): A preliminary study of dextromethorphan (DM) as adjunctive therapy in Parkinson's Disease (PD). Neurology 43: A155

Scatton B, Avenet P, Benavides I, Carter C, Duverger D, Oblin A, Perrault G, Sanger DJ, Shoemaker H (1994): Neuroprotective potential of the polyamine site-directed NMDA receptor antagonists-ifenprodil and eliprodil. In Palfreyman MG, Reynolds IJ, Skolnick P (eds), Direct and Allosteric Control of Glutamate Receptors, Boca Raton, FL, CRC Press, pp 139-154 
Schoepp DD, Ornstein PL, Salhoff CR, Leander JD (1991): Neuroprotectant effects of LY274614, a structurally novel systemically active competitive NMDA receptor antagonist. J Neural Transm 85:133-143

Singh L, Menzies R, Tricklebank MD (1990): The discriminative stimulus properties of (+)-HA-966, an antagonist at the glycine/N-methyl-D-aspartate receptor. Eur J Pharmacol 186:129-132

Smits EE (1976): Antagonism by naloxone of morphineinduced single-dose dependence and antinociception in mice. Res Commun Chem Path Pharmacol 15:689-696

Snyder SH, Bredt S (1991): Nitric oxide as a neuronal mes. senger. Trends Pharmacol Sci 12:125-128

Sommer B, Seeburg PH (1992): Glutamate receptor channels-novel properties and new clones. Trends Pharmacol Sci 13:291-296

Sugiyama H, Ito I, Hiron C (1987): A new type of glutamate receptor linked to inositol phospholipid metabolism. Nature 325:531-533

Székely JI (1994): Opioid Peptides in Substance Abuse. Boca Raton, FL, CRC Press

Takemori AE, Loh HH, Lee NM (1992): Supression by dynorphin $A(1-13)$ of the expression of opioid withdrawal and tolerance in mice. Eur J Pharmacol 221:223-226

Takemori AE, Loh HH, Lee NM (1993): Suppression by Dynorphin $A$ and [Des-Tyr ${ }^{1}$ ] Dynorphin A peptides of the expression of opiate withdrawal and tolerance in morphine-dependent mice. J Pharmacol Exp Ther 266:121-124

Tanganelli S, Antonelli T, Morari M, Bianchi C, Beani L (1991): Glutamate antagonists prevent morphine withdrawal in mice and guinea pigs. Neurosci Lett 122:270-272

Thorat SN, Bhargava HN (1995): Competitive antagonism of NMDA receptor inhibits the development of tolerance to a kappa-opioid receptor agonist in mice. FASEB J Abstr 9:A102

Thorat SN, Reddy PL, Bhargava HN (1993): Evidence for the role of nitric oxide in kappa-opioid tolerance in mice. Brain Res 621:171-174

Thorat SN, Barjavel M, Matwyshyn GA, Bhargava HN (1994): Comparative effects of $\mathrm{N}^{\mathrm{G}}$-monomethyl-L-arginine and MK-801 on the abstinence syndrome in morphinedependent mice. Brain Res 642:153-159

Tiseo PJ, Inturrisi CE (1993): Attenuation and reversal of morphine tolerance by the competitive $\mathrm{N}$-methyl-D-aspartate receptor antagonist, LY274614. I Pharmacol Exp Ther 264:1090-1096

Tiseo PJ, Cheng J, Pasternak GW, Inturrisi CE (1994): Modulation of morphine tolerance by the competitive N-Methyl-D-Aspartate receptor antagonist LY274614: Assessment of Opioid Receptor Changes. J Pharmacol Exp Ther 268:195-201

Tremblay E, Colombel MC, Jacob I (1976): Précipitation et prévention de l'abstinence chez le rat et la souris en état de dépendence aiguë: comparison de la diprenorphine. Psychopharmacology 49:41-48

Trujillo KA (1995): Effects of noncompetitive N-methyl-Daspartate receptor antagonists on opiate tolerance and physical dependence. Neuropsychopharmacology 13: 301-307

Trujillo KA, Akil H (1991a): Inhibition of morphine tolerance and dependence by the NMDA receptor antagonist MK801. Science 251:85-87

Truijllo KA, Akil H (1991b): The NMDA receptor antagonist MK-801 increases morphine catalepsy and lethality. Pharmacol Biochem Behav 38:673-675

Trujillo KA and Akil H (1994): Inhibition of opiate tolerance by non-competitive $\mathrm{N}$-methyl-D-aspartate receptor antagonists. Brian Res 633:178-188

Trullas R, Folio T, Young A, Miller R, Boje K, Skolnick P (1991): I-Aminocyclopropanecarboxylates exhibit antidepressant and anxiolytic actions in animal models. Eur J Pharmacol 203:379-385

Tulnay FC, Jen M-F, Chang J-K, Loh HH, Lee NM (1981): Possible regulatory role of dynorphin on morphine- and B-endorphin-induced analgesia. J Pharmacol Exp Ther 219:296-298

Vaupel DB, Kimes AS, London ED (1995): Comparison of 7-nitroindazole with other nitric oxide synthase inhibitors as attenuators of opioid withdrawal. Psychopharmacology 118:361-368

Vaupel DB, Kimes AS, London ED (1995): Nitric oxide synthase inhibitors: preclinical studies of potential use for treatment of opiate addiction. Neuropsychopharmacology 13:315-322

Watkins JC (1978): Excitatory amino acids. In McGeer E, Olney JW, McGeer P (eds), Kainic Acid as a Tool in Neurobiology, New York, Raven, pp 37-69

Watkins JC, Evans RH (1981): Excitatory amino acid transmitters. Ann Rev Pharmacol Toxicol 21:166-210

Watkins L, Kinschenck IB, Mayer DJ (1984): Potentiation of morphine analgesia and apparent reversal of morphine tolerance by proglumide. Science 224:395-396

Watson GB, Lanthorn TH (1990): Pharmacological characteristics of cyclic homologues of glycine at the N-methyl-Daspartate receptor-associated glycine site. Neuropharmacol 29:727-730

Willetts J, Balster RL, Leander JD (1990): The behavioral pharmacology of NMDA receptor antagonists. Trends Pharmacol Sci $11: 423-428$

Williams K, Romano C, Dichter MA, Molinoff PB (1991): Minireview. Modulation of the NMDA receptor by polyamines. Life Sci 48:469-498

Wong EHF, Kemp JA (1991): Sites for antagonism on the $\mathrm{N}$-methyl-D-aspartate receptor channel complex. Annu Rev Pharmacol Toxicol 31:401-425

Xie CW, Lewis DV (1991): Opioid-mediated facilitation of longterm potentiation at the lateral perforant path-dentate granule cell synapse. J Pharmacol Exp Ther 256:289-296

Xie Q, Cho HJ, Calaycay J, Mumford RA, Swidereck KM, Lee TD. Ding A, Troso T, Nathans C (1992): Science 256: 225-228

Yano l, Takemori AE (1977): Inhibition by naloxone of tolerance and dependence in mice treated acutely and chronically with morphine. Res Commun Chem Pathol Pharmacol 16:721-734

Zysset T, Fengin T, Kupfer A (1988): In-vivo and in vitro dextromethorphan metabolism in SD and DA rat: An animal model of the debrisoquine-type polymorphic oxidation in man. Biochem Pharmacol 37:3155-3160 